\title{
Upstream flow effects revealed in the EastGRIP ice core using Monte Carlo inversion of a two-dimensional ice-flow model
}

\author{
Tamara Annina Gerber ${ }^{1}$, Christine Schøtt Hvidberg ${ }^{1}$, Sune Olander Rasmussen ${ }^{1}$, Steven Franke ${ }^{2}$, Giulia Sinnl ${ }^{1}$, \\ Aslak Grinsted ${ }^{1}$, Daniela Jansen ${ }^{2}$, and Dorthe Dahl-Jensen ${ }^{1,3}$ \\ ${ }^{1}$ Section for the Physics of Ice, Climate and Earth, Niels Bohr Institute, University of Copenhagen, \\ Copenhagen, Denmark \\ ${ }^{2}$ Alfred Wegener Institute, Helmholtz Centre for Polar and Marine Research, Bremerhaven, Germany \\ ${ }^{3}$ Centre for Earth Observation Science, University of Manitoba, Winnipeg, Canada
}

Correspondence: Tamara Annina Gerber (tamara.gerber@nbi.ku.dk)

Received: 18 February 2021 - Discussion started: 23 February 2021

Revised: 28 June 2021 - Accepted: 7 July 2021 - Published: 6 August 2021

\begin{abstract}
The Northeast Greenland Ice Stream (NEGIS) is the largest active ice stream on the Greenland Ice Sheet (GrIS) and a crucial contributor to the ice-sheet mass balance. To investigate the ice-stream dynamics and to gain information about the past climate, a deep ice core is drilled in the upstream part of the NEGIS, termed the East Greenland Ice-core Project (EastGRIP). Upstream flow can introduce climatic bias into ice cores through the advection of ice deposited under different conditions further upstream. This is particularly true for EastGRIP due to its location inside an ice stream on the eastern flank of the GrIS. Understanding and ultimately correcting for such effects requires information on the atmospheric conditions at the time and location of snow deposition. We use a two-dimensional Dansgaard-Johnsen model to simulate ice flow along three approximated flow lines between the summit of the ice sheet (GRIP) and EastGRIP. Isochrones are traced in radio-echo-sounding images along these flow lines and dated with the GRIP and EastGRIP ice-core chronologies. The observed depth-age relationship constrains the Monte Carlo method which is used to determine unknown model parameters. We calculate backwardin-time particle trajectories to determine the source location of ice found in the EastGRIP ice core and present estimates of surface elevation and past accumulation rates at the deposition site. Our results indicate that increased snow accumulation with increasing upstream distance is predominantly responsible for the constant annual layer thicknesses observed in the upper part of the ice column at EastGRIP, and the inverted model parameters suggest that basal melting and slid-
\end{abstract}

ing are important factors determining ice flow in the NEGIS. The results of this study form a basis for applying upstream corrections to a variety of ice-core measurements, and the inverted model parameters are useful constraints for more sophisticated modelling approaches in the future.

\section{Introduction}

The East Greenland Ice-core Project (EastGRIP) is the first attempt to retrieve a deep ice core inside an active ice stream. The drill site is located in the upstream part of the Northeast Greenland Ice Stream (NEGIS; Fahnestock et al., 1993), which is a substantial contributor to the Greenland Ice Sheet (GrIS) mass balance (Khan et al., 2014) and accounts for around $12 \%$ of its total ice discharge (Rignot and Mouginot, 2012). Large-scale ice-sheet models are essential tools to anticipate the future development of the NEGIS and its potential impact on the stability of the GrIS (Joughin et al., 2001; Khan et al., 2014; Vallelonga et al., 2014). However, results obtained from such models often show a significant deviation from observed surface velocities in the NEGIS and its catchment area (Aschwanden et al., 2016; Mottram et al., 2019). In particular, the high ice-flow velocities in the upstream area of the NEGIS and the clearly defined shear margins are difficult to reproduce with ice-flow models (Beyer et al., 2018). A recent study by Smith-Johnsen et al. (2020a) showed that the high surface velocities in the onset region of the ice stream could be reproduced with their model, using an exceptionally 
high and geologically unfeasible geothermal heat flux (Bons et al., 2021). This indicates that additional, yet unknown, processes must facilitate ice flow in the NEGIS and that the driving mechanisms governing ice flow are still not understood well enough. The EastGRIP ice core sheds some light on the key processes by revealing unique information about ice dynamics, stress regimes, temperatures and basal properties, all of which are crucial components in ice-flow models.

Chemical and physical properties measured in ice cores reflect the atmospheric conditions at the time and location of snow deposition (e.g. Alley et al., 1993; Petit et al., 1999; Andersen et al., 2004; Marcott et al., 2014). Most of the deep drilling projects in Greenland and Antarctica are located in slow-moving areas at ice domes or near ice divides (e.g. GRIP - Dansgaard et al., 1982; Dome Fuji - Ageta et al., 1998; Dome C - Parrenin et al., 2007), so the ice core can be expected to represent climate records from this fixed location. For ice cores drilled on the flank of an ice sheet (e.g. GISP2 - Meese et al., 1997; Vostok - Lorius et al., 1985; Petit et al., 1999) or in areas with higher flow velocities (e.g. Camp Century - Dansgaard and Johnsen, 1969; Byrd Gow et al., 1968; NorthGRIP - Andersen et al., 2004; EDML - Barbante et al., 2006; WAIS Divide - Fudge et al., 2013; NEEM - NEEM Community members et al., 2013), the ice found at depth was originally deposited further upstream and advected with the horizontal flow.

The spatial variation in accumulation rate, surface temperature and atmospheric pressure can introduce climatic imprints into the ice-core record which stem from the advection of ice deposited under different conditions further upstream. The ice core signal is thus a combination of temporal and spatial variations in climatic components (Fudge et al., 2020). The magnitude of these so-called upstream effects depends on the ice-flow velocity, spatial variability in the precipitation and the sensitivity to atmospheric variations in the quantity under consideration. While well-mixed atmospheric gases, such as carbon dioxide or methane, and drydeposited impurities are barely affected (Fudge et al., 2020), properties extracted from the ice phase can show significant bias. Affected measurements include aerosols and cosmogenic isotopes, such as ${ }^{10} \mathrm{Be}$ (Yiou et al., 1997; Finkel and Nishiizumi, 1997; Raisbeck et al., 2007; Delaygue and Bard, 2011), the isotopic composition of water (Dansgaard, 1964; Jouzel et al., 1997; Aizen et al., 2006), the total air content (Raynaud et al., 1997; Eicher et al., 2016) and ice temperatures (Salamatin et al., 1998). Processes such as vertical thinning of the ice column and firn densification are also influenced by upstream effects and have consequences on the annual layer thicknesses (Dahl-Jensen et al., 1993; Rasmussen et al., 2006; Svensson et al., 2008) and the age difference between ice and the enclosed air (Herron and Langway, 1980; Alley et al., 1982). Upstream effects in the EastGRIP ice core are expected to be particularly strong due to the fast ice flow in the upstream area ( $57 \mathrm{ma}^{-1}$ at EastGRIP; Hvidberg et al., 2020), the strong gradient in the accumulation rate across
Greenland's main ice ridge (Burgess et al., 2010) and the increasing elevation towards the central ice divide (Simonsen and Sørensen, 2017). The correction of these effects in the EastGRIP ice core is necessary to interpret the ice-core measurements within the climatic context and requires information on the conditions at the time and location of snow deposition.

Post-depositional deformation of isochrones observed in radio-echo-sounding (RES) images along flow lines provides information on ice-flow dynamics and can be used to reconstruct past and present flow characteristics. In this study, we use a vertically two-dimensional Dansgaard-Johnsen model to simulate the propagation and deformation of isochrones along three approximated flow lines between the ice-sheet summit (GRIP) and EastGRIP. A Monte Carlo method is used to determine the unknown model parameters by minimizing the misfit between modelled and observed data. The latter includes the depth of isochrones observed in RES images along the flow lines and a parameter $\alpha_{\text {sur }}$ representing the sum of the horizontal strain rates deduced from satellitebased surface velocities. From the modelled velocity field, we calculate particle trajectories backwards in time to infer the source location of ice found in the EastGRIP ice core and estimate the accumulation rate at the time of snow deposition. The source characteristics presented here form a basis to correct for upstream effects in various chemical and physical quantities of the EastGRIP ice core. These corrections are important to remove any climatic bias in ice-core measurements which are currently being analysed and will become available in the future. The inverted model parameters give insight into basal properties and ice-flow dynamics along the flow lines and can be used to constrain more sophisticated numerical models of the NEGIS.

\section{Data and methods}

Snow layers deposited at the surface of ice sheets are buried with time and are deformed as a consequence of ice flow. While these isochrones can be observed in RES images today, the ice-flow characteristics which shaped them are generally unknown. This is a typical geophysical inverse problem and can be formulated as $\boldsymbol{d}=g(\boldsymbol{m})$, where the function $g(\boldsymbol{m})$ represents the ice-flow model linking the model parameters $(\boldsymbol{m})$ with the observed data $(\boldsymbol{d})$. A variety of inverse methods exist to find the model parameters which reproduce the observed data within their uncertainties. Here, we use a Markov chain Monte Carlo method to determine the unknown parameters of a two-dimensional ice-flow model by minimizing the misfit between modelled and observed isochrones and strain rates. This allows us to reconstruct the ice-flow characteristics in the past and to determine the flow trajectories of the EastGRIP ice. 

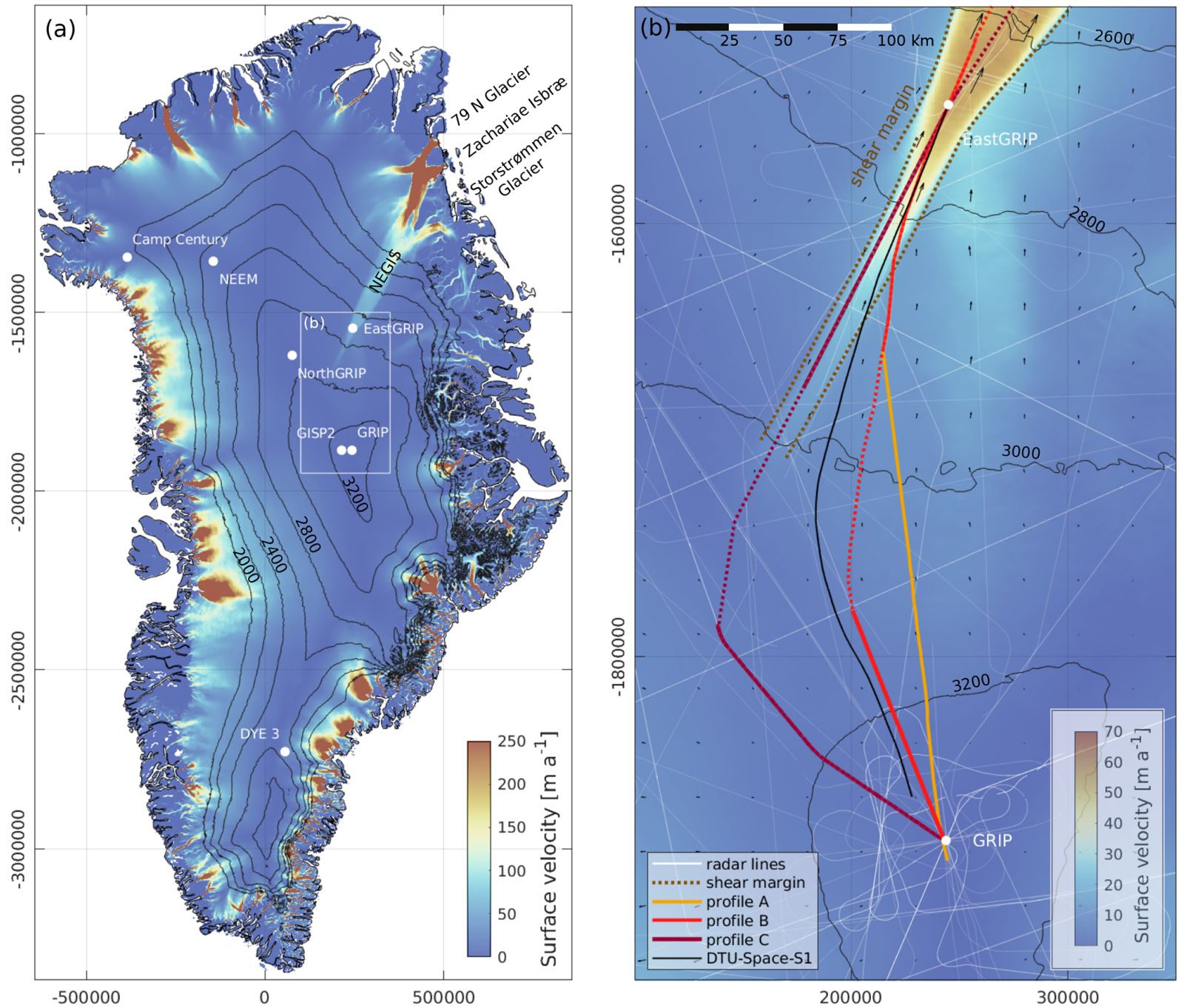

Figure 1. (a) Overview of past and ongoing deep ice-core drilling projects on the GrIS (surface elevation and Greenland contour lines by Simonsen and Sørensen, 2017; Greene et al., 2017) and the outline of the study area. The NEGIS appears as a distinct feature in the surface velocities (Joughin et al., 2018). It extends from the central ice divide to the northeastern coast, where it splits up into the three marineterminating glaciers: 79N Glacier, Zachariae Isbræ and Storstrømmen Glacier. (b) The present-day EastGRIP flow line is derived from the DTU-Space-S1 surface velocity product (Andersen et al., 2020). Due to the limited availability of radar data along the flow line, we construct three approximate flow lines through a combination of various radar products (profile A-C) between GRIP and EastGRIP. Flow line B and C lack data in the centre of the profiles, marked as a dashed line. The downstream parts of line A and B comprise the same radar profile, which crosses the southern shear margin around $82 \mathrm{~km}$ upstream of EastGRIP.

Table 1. RES profiles used to approximate the EastGRIP flow lines A-C. The data sets were measured between 1999 and 2018 by the Center for Remote Sensing of Ice Sheets (CReSIS; CReSIS, 2021) and the Alfred Wegener Institute, Helmholtz Centre for Polar and Marine Research (AWI; Jansen et al., 2020; Franke et al., 2021b).

\begin{tabular}{lllll}
\hline Flow line & Data files & Institution & Year & Radar system \\
\hline A & Data_20180512_01_001-004 & AWI & 2018 & MCoRDS 5 \\
A & Data_19990512_01_009-010 & CReSIS & 1999 & ICORDS 2 \\
B & Data_20180512_01_001-004 & AWI & 2018 & MCoRDS 5 \\
B & Data_19990523_01_016-017 & CReSIS & 1999 & ICORDS 2 \\
C & Data_20180517_01_002-004 & AWI & 2018 & MCoRDS 5 \\
C & Data_20120330_03_008-011 & CReSIS & 2012 & MCoRDS 2 \\
\hline
\end{tabular}


Table 2. Operating parameters of the radar systems used for data acquisition. Further details can be found in Gogineni et al. (2001), Byers et al. (2012) and Franke et al. (2021b).

\begin{tabular}{llll}
\hline Parameter & ICORDS 2 & MCoRDS 2 & MCoRDS 5 \\
\hline Bandwidth & $141.5-158.5 \mathrm{MHz}$ & $180-210 \mathrm{MHz}$ & $180-210 \mathrm{MHz}$ \\
Tx power & $200 \mathrm{~W}$ & $1050 \mathrm{~W}$ & $6000 \mathrm{~W}$ \\
Waveform & Analogue chirp $\left(\mathrm{SAW}^{*}\right)$ & 8 -channel chirp (two-three waveforms) & 8 -channel chirp (three waveforms) \\
Sampling frequency & $18.75 \mathrm{MHz}$ & $111 \mathrm{MHz}$ & $1600 \mathrm{MHz}$ \\
Transmit channels & 1 & 8 & 8 \\
Receiving channels & 1 & 15 & 8 \\
Range resolution & $7.6 \mathrm{~m}$ & $4.3 \mathrm{~m}$ & $4.3 \mathrm{~m}$ \\
\hline
\end{tabular}

* SAW: surface acoustic wave.

Table 3. Characteristics of the traced isochrones connecting the GRIP and EastGRIP ice-core sites. Displayed depths and ages are the average over the three flow lines. Depth uncertainties include the uncertainty related to the picking process and to the radar range resolution. Age uncertainties are related to the GICC05 timescale uncertainties and isochrone depths. Figure 7d illustrates the depth and climatic context of these layers in the EastGRIP ice core, identified with the corresponding layer numbers. The bold layers and the EastGRIP ages were used for the Monte Carlo inversion and are illustrated with a consistent colour code in Figs. 4, 5 and 7.

\begin{tabular}{lrrrr}
\hline Layer & GRIP depth $[\mathrm{m}]$ & EastGRIP depth $[\mathrm{m}]$ & GRIP age [years b2k] & EastGRIP age [years b2k] \\
\hline 1 & $733 \pm 13$ & $421 \pm 11$ & $3618 \pm 73$ & $3498 \pm 94$ \\
$\mathbf{2}$ & $\mathbf{7 9 5} \pm \mathbf{1 3}$ & $\mathbf{4 7 1} \pm \mathbf{1 1}$ & $\mathbf{4 0 0 4} \pm \mathbf{7 4}$ & $\mathbf{3 9 4 5} \pm \mathbf{9 5}$ \\
3 & $925 \pm 13$ & $573 \pm 11$ & $4885 \pm 85$ & $4805 \pm 93$ \\
$\mathbf{4}$ & $\mathbf{1 2 1 7} \pm \mathbf{1 3}$ & $\mathbf{8 3 8} \pm \mathbf{1 1}$ & $\mathbf{7 1 7 8} \pm \mathbf{1 0 6}$ & $\mathbf{7 1 3 9} \pm \mathbf{9 5}$ \\
5 & $1262 \pm 13$ & $882 \pm \mathbf{1 1}$ & $7575 \pm 107$ & $\mathbf{7 5 3 1} \pm 95$ \\
$\mathbf{6}$ & $\mathbf{1 3 4 7} \pm \mathbf{1 3}$ & $\mathbf{9 6 8} \pm \mathbf{1 1}$ & $\mathbf{8 3 6 4} \pm \mathbf{1 2 2}$ & $\mathbf{8 3 2 1} \pm \mathbf{1 1 0}$ \\
7 & $1374 \pm 13$ & $996 \pm 11$ & $8637 \pm 124$ & $8600 \pm 113$ \\
8 & $1533 \pm 13$ & $1153 \pm \mathbf{1 1}$ & $10407 \pm 162$ & $10365 \pm 149$ \\
$\mathbf{9}$ & $\mathbf{1 5 9 2} \pm \mathbf{1 3}$ & $\mathbf{1 2 0 8} \pm \mathbf{1 1}$ & $\mathbf{1 1 2 0 9} \pm \mathbf{1 8 1}$ & $\mathbf{1 1 1 4 0} \pm \mathbf{1 6 8}$ \\
10 & $1663 \pm 13$ & $1282 \pm 11$ & $12891 \pm 327$ & $12822 \pm 290$ \\
$\mathbf{1 1}$ & $\mathbf{1 7 4 9} \pm \mathbf{1 3}$ & $\mathbf{1 3 5 5} \pm \mathbf{1 1}$ & $\mathbf{1 4 6 1 2} \pm \mathbf{2 8 1}$ & $\mathbf{1 4 3 5 0} \pm \mathbf{2 0 6}$ \\
$\mathbf{1 2}$ & $\mathbf{2 0 3 9} \pm \mathbf{1 3}$ & $\mathbf{1 7 0 4} \pm \mathbf{1 1}$ & $\mathbf{2 8 6 3 3} \pm \mathbf{8 4 0}$ & $\mathbf{2 8 5 2 2} \pm \mathbf{6 4 7}$ \\
$\mathbf{1 3}$ & $\mathbf{2 1 9 3} \pm \mathbf{1 3}$ & $\mathbf{1 9 0 3} \pm \mathbf{1 1}$ & $\mathbf{3 8 0 1 5} \pm \mathbf{9 9 4}$ & $\mathbf{3 7 9 1 4} \pm \mathbf{7 9 3}$ \\
$\mathbf{1 4}$ & $\mathbf{2 2 9 8} \pm \mathbf{1 3}$ & $\mathbf{2 0 3 5} \pm \mathbf{1 1}$ & $\mathbf{4 5 4 6 3} \pm \mathbf{1 1 8 9}$ & $\mathbf{4 5 1 7 4} \pm \mathbf{1 0 8 6}$ \\
$\mathbf{1 5}$ & $\mathbf{2 3 9 5} \pm \mathbf{1 3}$ & $\mathbf{2 1 5 2} \pm \mathbf{1 1}$ & $\mathbf{5 2 6 0 2} \pm \mathbf{1 3 6 0}$ & $\mathbf{5 1 9 2 0} \pm 1240$ \\
$\mathbf{1 6}$ & - & $\mathbf{2 3 6 0} \pm \mathbf{1 1}$ & & $\mathbf{7 2 4 0 0} \pm \mathbf{1 3 0 6}$ \\
\hline
\end{tabular}

In the coming sections we describe the data and methods underlying our results according to the workflow illustrated in Fig. 2.

In Sect. 2.1-2.3 we explain how the isochrone depth-age relationship constraining the Monte Carlo method was obtained. This involves the selection of RES images approximating the EastGRIP flow line (Sect. 2.1), extending the existing chronology of the EastGRIP ice core to the current drill depth (Sect. 2.2), and the tracing and dating of isochrones in the RES data (Sect. 2.3). In Sect. 2.4 the ice-flow model is described in detail, and in Sect. 2.5 we elaborate on the Monte Carlo method used for parameter sampling. The section numbers are displayed in the corresponding steps in Fig. 2.

\subsection{EastGRIP flow lines}

Determining the exact flow line through the EastGRIP icecore site is important to understanding the flow history of the survey area and enables us to reconstruct the location where the ice from the ice core was deposited at the icesheet surface. For this, we use high-resolution satellite-based surface velocity products (e.g. Joughin et al., 2018; Gardner et al., 2020; Andersen et al., 2020; see Fig. S1 in the Supplement) to calculate the upstream flow path. Minor uncertainties and bias in these data products affect along-flow tracing and lead to deviations between flow lines derived from different velocity maps. These deviations become more pronounced with increasing distance from the starting point, as the uncertainties propagate along the line and in general become larger in slow-moving areas of the ice sheet (Hvidberg et al., 2020). Due to the small bias, we consider the DTU- 


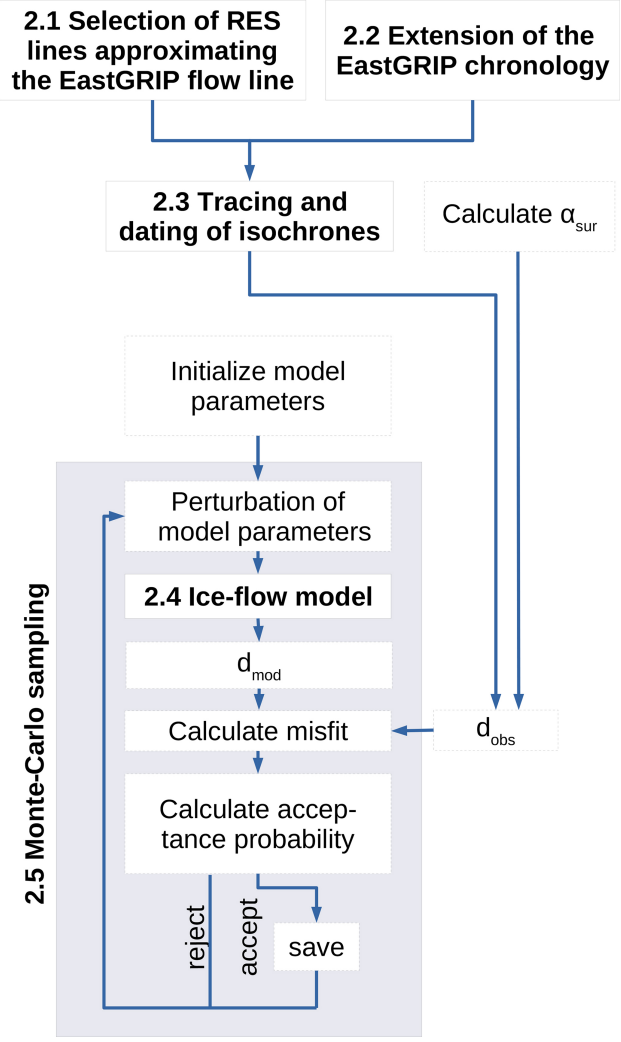

Figure 2. Workflow of the applied steps leading to the results described in Sect. 3. The main steps are described in Sect. 2.1-2.5 and marked with the corresponding numbers in the figure: the observed data $\left(\boldsymbol{d}_{\mathrm{obs}}\right)$ constraining the Monte Carlo method consist of the $\alpha_{\text {sur }}$ calculated from the ice surface velocities and the isochrone depths along the flow lines. The latter is obtained by approximating the EastGRIP flow line with selected RES images (Sect. 2.1), extending the EastGRIP chronology to the current drill depth (Sect. 2.2), and subsequent tracing and dating of isochrones (Sect. 2.3). The iterative Monte Carlo sampling process is illustrated in the grey box (Sect. 2.5) and includes data simulation by a Dansgaard-Johnsen ice-flow model described in Sect. 2.4.

Space-S1 (Andersen et al., 2020) line the most likely current flow line (Fig. 1b). Yet, there is no evidence that the presentday velocity field was the same in the past. A slight shift in the NEGIS shear margins or the central ice divide, for instance, would have a large effect on the velocity field, and, hence, the determination of the flow line of the EastGRIP ice remains ambiguous.

RES data reveal the internal structure of glaciers and ice sheets and provide valuable information on the ice-flow characteristics, particularly when recorded parallel to the ice flow. The electromagnetic waves used in RES are sensitive to contrasts in dielectric properties of the medium in which they propagate. In ice sheets, these contrasts arise through density variations in the uppermost part of the ice column (Robin et al., 1969), changes in the crystal orientation fabric (Harrison, 1973) and impurity layers such as volcanic deposits
(Paren and Robin, 1975). The latter is the most common reflector type below the firn (Millar, 1982; Eisen et al., 2006), and because it is related to layers deposited over a relatively short period of time, most internal reflection horizons (IRHs) detected by RES can be considered isochrones.

The availability of RES data in the study area is limited, and unfortunately, the flight lines generally do not follow the surface velocity field. We have thus composed three approximated flow lines connecting the EastGRIP $\left(75.63^{\circ} \mathrm{N}\right.$, $\left.35.99^{\circ} \mathrm{W} ; 2720 \mathrm{~m}\right)$ and the GRIP $\left(72.58^{\circ} \mathrm{N}, 37.63^{\circ} \mathrm{W}\right.$; $3230 \mathrm{~m}$ ) drill sites from the available RES data sets (Fig. 1b). The radar data used in this study (Table 1) were measured by the Alfred Wegener Institute, Helmholtz Centre for Polar and Marine Research (AWI; Jansen et al., 2020; Franke et al., 2021b) and the Center for Remote Sensing of Ice Sheets (CReSIS, 2021). The AWI data were recorded by an eight-antenna-element ultra-wideband radar system (MCoRDS 5) mounted on the Polar 6 Basler BT-67 aircraft, operating at a frequency range of $180-210 \mathrm{MHz}$ (Franke et al., 2020, 2021b). The CReSIS radar data were measured by an ICORDS 2 (1999) and a MCoRDS 2 (2012) radar system, mounted on a NASA P-3 aircraft, at a frequency range of $141.5-158.5$ and $180-210 \mathrm{MHz}$, respectively. Details of the three radar systems are provided in Table 2 .

The downstream parts of profile A and B consist of the same flight line, which passes through the EastGRIP drill site and intersects the southern shear margin around $82 \mathrm{~km}$ upstream of EastGRIP. Outside the NEGIS, the two lines split up and connect to two different RES profiles. Line B remains relatively close to the flow direction of the DTU-Space-S1 line but has a wide data gap in the centre of the profile. In line $\mathrm{A}$, this problem is circumvented by using a radar profile connecting directly to GRIP, which deviates from the observed surface flow field by more than $15^{\circ}$ at some locations. Profile $\mathrm{C}$ follows the NEGIS trunk all the way to the central ice divide and connects to GRIP over the ice ridge without crossing the shear margin. Similarly to flow line B, flow line $\mathrm{C}$ contains a substantial data gap between the onset region of the NEGIS and the central ice divide.

To avoid uncertainties related to the proximity of the model boundaries, the flow lines were extended more than $50 \mathrm{~km}$ beyond EastGRIP and have a total length of 422 (line A), 421 (line B) and $480 \mathrm{~km}$ (line C). To account for any differences in surface elevation or topography between RES data from different years, the ice surface reflections of the radar profiles were aligned to the surface elevation from ArcticDEM (Porter et al., 2018). The bed topography in the data gaps of the profiles was derived from the BedMachine v3 data set (Morlighem et al., 2017).

\subsection{Extending the chronology of EastGRIP from GS-2 to GI-14}

The validation of our modelling results and the correct dating of isochrones requires a reliable depth-age scale. The Green- 


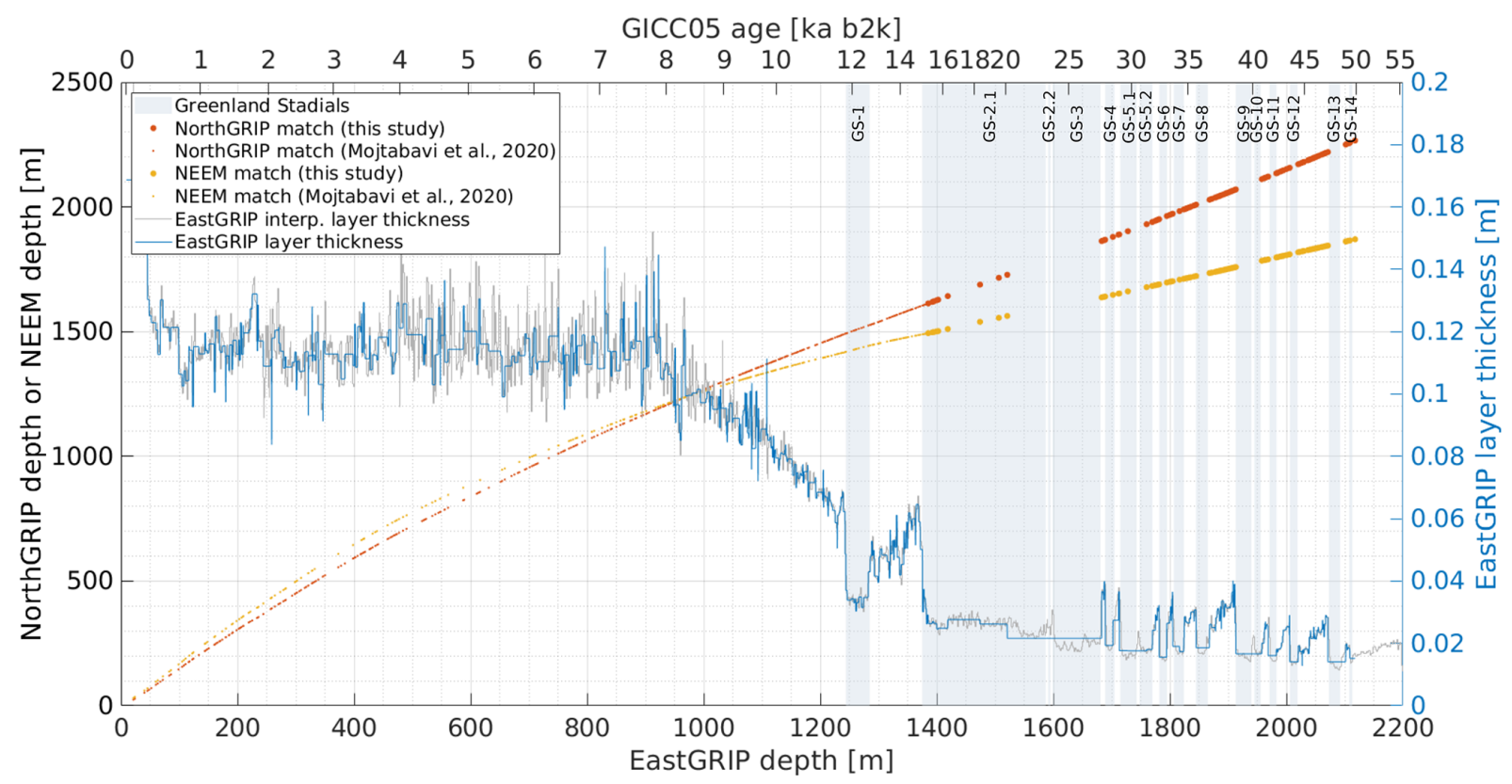

Figure 3. Synchronization between the EastGRIP, NorthGRIP and NEEM ice cores and comparison of match points obtained in this study with earlier results from Mojtabavi et al. (2020). The annual layer thickness of EastGRIP was computed after transferring GICC05 ages by linear interpolation to the EastGRIP ice core. The blue curve shows the annual layer thickness obtained by the match points only. The grey line indicates a high-resolution estimate of annual layer thicknesses at EastGRIP, obtained from the linear interpolation between the EastGRIP-NorthGRIP match points and assigning the interpolated EastGRIP depths to the NorthGRIP ages.

land Ice Core Chronology 2005 (GICC05; Vinther et al., 2006; Rasmussen et al., 2006; Andersen et al., 2006; Svensson et al., 2006) is based on annual layer counting in various Greenland ice cores. It has been transferred to GRIP and other deep drilling sites in Greenland by synchronizing the ice cores with each other using horizons of, for example, volcanic origin (Rasmussen et al., 2008; Seierstad et al., 2014). The upper $1383.84 \mathrm{~m}$ of the EastGRIP ice core was drilled between 2015 and 2018 and synchronized with the NorthGRIP ice core in previous work (Mojtabavi et al., 2020).

By 2019, the ice-core drilling progressed down to $2122.45 \mathrm{~m}$, allowing us to extend the existing timescale from $15 \mathrm{kyr}$ to $49.9 \mathrm{kyrb} 2 \mathrm{k}$ (thousands of years before $2000 \mathrm{CE}$ ). As part of the present study, we identified common isochrones between EastGRIP, NorthGRIP and NEEM to transfer the GICC05 chronology to the part of the EastGRIP record which is not yet synchronized. This involved the same methods applied to NEEM by Rasmussen et al. (2013) and to the upper $1383.84 \mathrm{~m}$ of EastGRIP by Mojtabavi et al. (2020). The isochrones chosen for synchronization purposes are mainly volcanic eruptions, which are registered as brief spikes in the electrical conductivity measurements (ECMs; Hammer, 1980). The search of common ECM spikes was performed manually with a strong focus on finding patterns of similarly spaced eruptions rather than single and isolated events. The MATLAB program "Matchmaker" was used to visualize long data stretches and to evaluate the quality of the match (Rasmussen et al., 2008). An iterative multi-observer protocol was applied to reduce problems with confirmation bias and to ensure the reproducibility of the match.

A total of 138 match points were identified between 1383.84 and $2117.77 \mathrm{~m}$, adding to the previously known 381 match points. The match points between EastGRIP and the other two cores are shown in Fig. 3, representing all the volcanic tie points. The GICC05 chronology was transferred to EastGRIP by linear interpolation of depths between the match points. The age of the $1383.84 \mathrm{~m}$ match point was already established to be 14966 yearsb2k, which is near the termination of Greenland Stadial 2 (GS-2), with a reported maximum counting error (MCE) of 196 years (Mojtabavi et al., 2020). The age of the deepest match point was established to be 49909 years b2k, just at the end of Greenland Interstadial 14 (GI-14), with an MCE of 2066 years.

As in earlier similar work (e.g. Rasmussen et al., 2013; Seierstad et al., 2014), very few match points were observed in the stadials, most clearly seen in Fig. 3 in the long stadial stages of GS-2 and GS-3. The sparse volcanic signals within stadial periods should not be attributed to diminished global volcanic activity but rather to increased deposition of alkaline dust that neutralizes volcanic acid, caused by the prevailing colder and drier climatic conditions (Rasmussen et al., 2013). The largest distance between match points was observed across GS-2 and GS-3 and spans about $162 \mathrm{~m}$ of EastGRIP ice. 


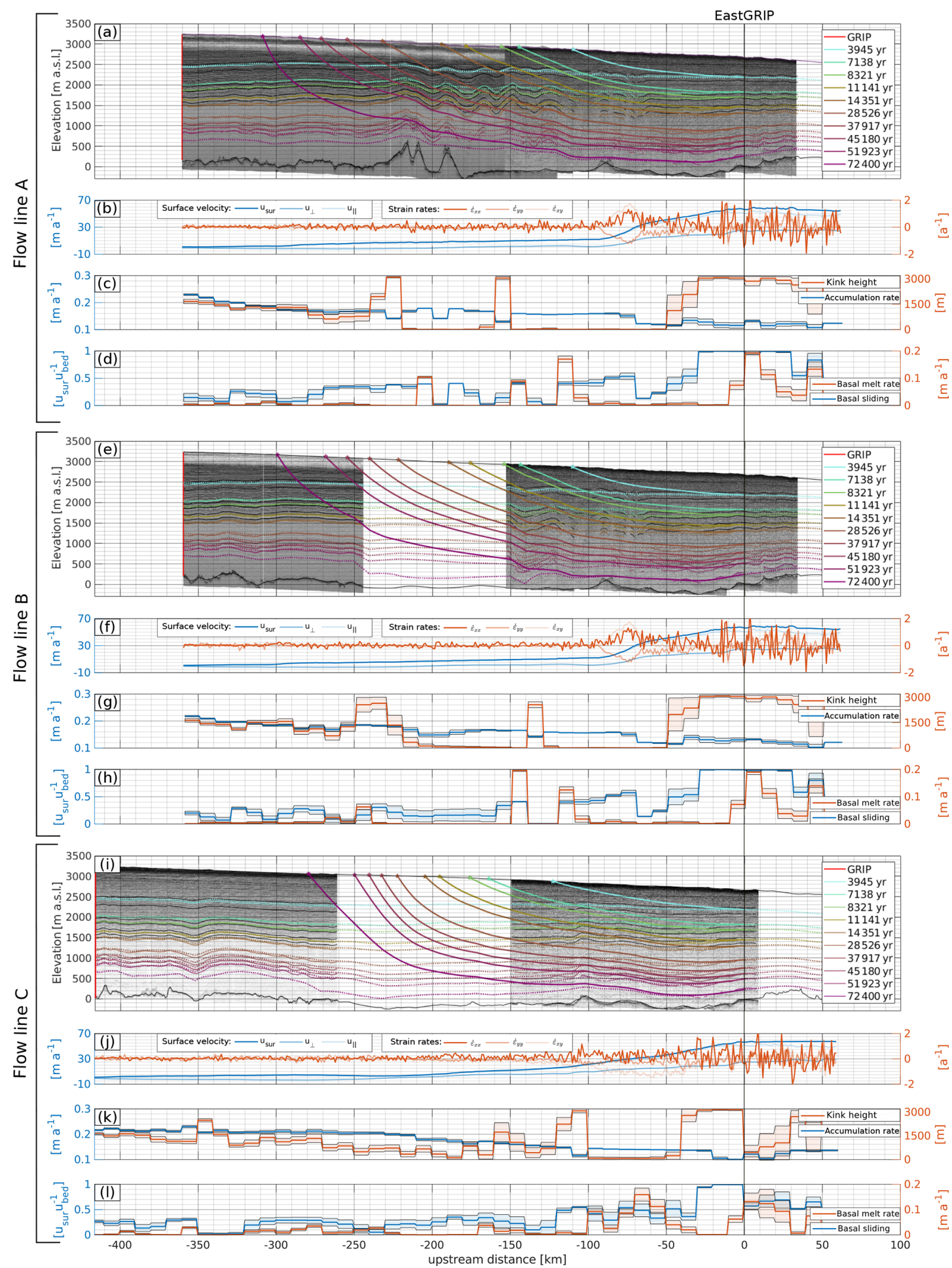

Figure 4. Flow-line characteristics and model parameters for the approximated flow lines A (a-d), B (e-h), and C (i-l). IRHs were traced (thin solid lines) in the RES images and simulated (dashed lines) with a two-dimensional Dansgaard-Johnsen model (a, e, i). From the modelled velocity field, we calculated particle trajectories (thick solid lines) backwards in time to obtain estimates of the source location for specific depths in the EastGRIP ice core. The colours of the lines indicate the age of the isochrones and the respective time of snow deposition and are identical to the colour code in Figs. 5 and 7. The horizontal strain rates at the surface were calculated from the MEaSUREs Multi-year v1 (Joughin et al., 2018) surface velocities (b, f, j). The mean and standard deviations of the sampled model parameters accumulation rate, kink height, basal melt rate and basal sliding $(\mathbf{c}, \mathbf{d}, \mathbf{g}, \mathbf{h}, \mathbf{k}, \mathbf{l})$ were obtained from a Monte Carlo inversion by reducing the misfit between observed and simulated data. All panels are aligned at EastGRIP, and the $x$ axis indicates the distance from the borehole location. 


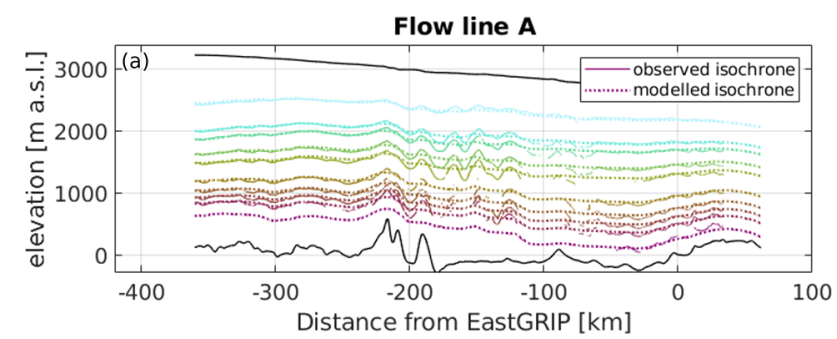

Flow line B

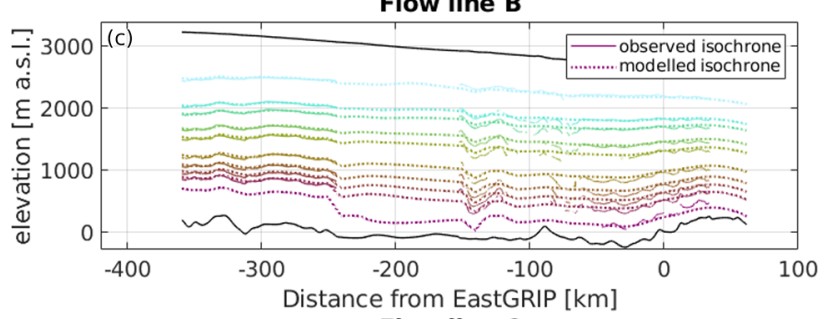

Flow line $C$

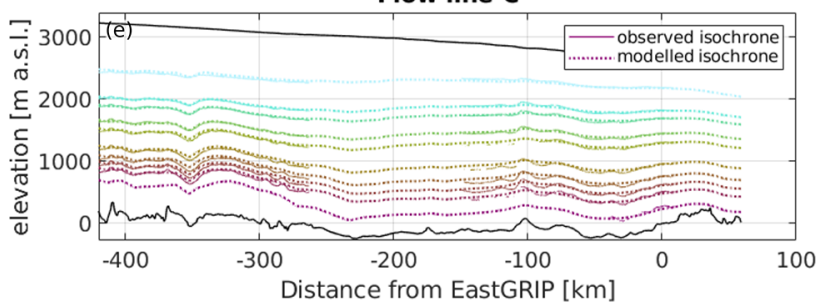

Flow line A
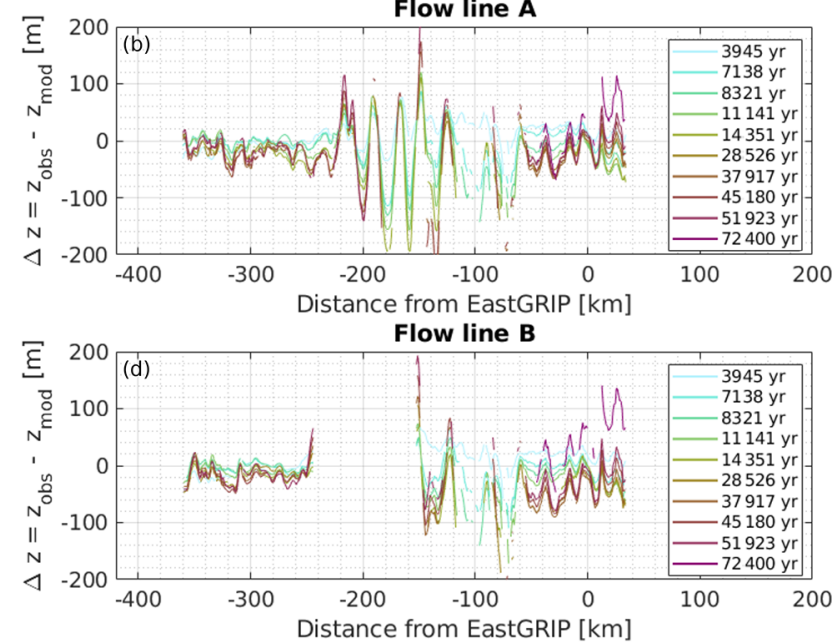

Flow line C

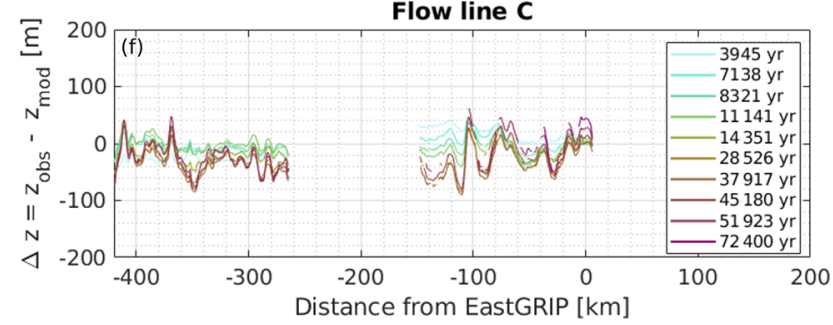

Figure 5. (a, c, e) Modelled and observed isochrones for profile A-C. The model fits the isochrones well in general but fails to reproduce strong layer undulations over short distances, leading to a larger misfit $(\mathbf{b}, \mathbf{d}, \mathbf{f})$ where such undulations are present. A positive misfit indicates that the modelled isochrone depth is overestimated which happens in particular for the deepest isochrone towards the end of flow line A and B. As in Figs. 4 and 7, the colour code represents the age of the corresponding isochrone.

\subsection{Tracing and dating of isochrones}

The depth-age relationship from ice-core chronologies can be extended in the lateral plane by tracing and dating of isochrones in RES images. The depth of these isochrones along the EastGRIP flow lines is part of the observed data used to tune the ice-flow model parameters in the Monte Carlo inversion. We traced 15 continuous IRHs and one noncontinuous reflector along each of the three approximated flow lines with a semi-automatic MATLAB program called "picking tool". The algorithm is based on calculating the local slope in each pixel of the RES image, and layers are traced automatically between two user-defined points. Starting from each of these points, the algorithm walks along the steepest slope towards the other point. Subsequently, the two lines are weighted by distance to their starting point and combined into one layer. The number of picks required for thorough tracing depends on the data quality and reflector strength.

The total depth uncertainty $\left(\tilde{z}_{\mathrm{t}}\right)$ was calculated as

$\tilde{z}_{\mathrm{t}}=\sqrt{\tilde{z}_{\mathrm{p}}^{2}+\tilde{z}_{r r}^{2}}$,

where the depth uncertainty introduced during the picking process $\left(\tilde{z}_{\mathrm{p}}\right)$ is estimated to be $10 \mathrm{~m}$. The uncertainty related to the radar range resolution $\left(\tilde{z}_{r r}\right)$ of the corresponding RES image is defined as

$\tilde{z}_{r r}=\frac{k c}{2 B \sqrt{3.15}}$,

where $k$ is the window widening factor of $1.53, c$ is the speed of light, $B$ is the radar bandwidth and 3.15 is the relative dielectric permittivity of ice.

The traced IRHs were dated at both drill sites by assigning the reflector depth at GRIP and EastGRIP to the corresponding timescale. In doing so, local irregularities were smoothed out by averaging the depth over $\pm 250 \mathrm{~m}$ around the trace closest to the ice-core location. Because the EastGRIP ice core has not reached the bed yet, we extrapolated the timescale at EastGRIP with two IRHs observed below the current borehole depth to obtain a tentative depth-age relationship between $2117.77 \mathrm{~m}$ and the expected bed depth of $2668 \mathrm{~m}$.

The total age uncertainty $\left(\tilde{a}_{\mathrm{t}}\right)$ was estimated by following the approach described in MacGregor et al. (2015), where

$\tilde{a}_{\mathrm{t}}=\sqrt{\tilde{a}_{\mathrm{c}}^{2}+\tilde{a}_{r r}^{2}+\tilde{a}_{\mathrm{p}}^{2}}$

takes into account the age uncertainties associated with the timescale ( $\tilde{a}_{\mathrm{c}}$, equivalent to a $\left.0.5 \mathrm{MCE}\right)$, the radar range res- 
olution $\left(\tilde{a}_{r r}\right)$ and the layer picking process $\left(\tilde{a}_{\mathrm{p}}\right)$. The uncertainties related to the range resolution are estimated with

$\tilde{a}_{r r}=\frac{1}{2} \sum\left|a_{\mathrm{c}}\left(z \pm \tilde{z}_{r r}\right)-a_{\mathrm{c}}(z)\right|$,

where $a_{\mathrm{c}}$ is the ice-core age from the GICC05 timescale. Similarly to Eq. (4), $\tilde{a}_{\mathrm{p}}$ is estimated with

$\tilde{a}_{\mathrm{p}}=\frac{1}{2} \sum\left|a_{\mathrm{c}}\left(z \pm \tilde{z}_{\mathrm{p}}\right)-a_{\mathrm{c}}(z)\right|$.

The chosen isochrones show distinct patterns which could be identified in all RES images and allowed us to trace isochrones across disruptions and data gaps. Comparison of the isochrone depths at the ice-core locations obtained from different RES images permits assessment of the quality of the tracing procedure. The high resolution of the radar images recorded in 2018 facilitates isochrone tracing, and the EastGRIP depths obtained from the two different AWI radar profiles agree to within $1.5 \mathrm{~m}$. At GRIP, the discrepancy between isochrone depths obtained from three different radar profiles can be up to $30 \mathrm{~m}$, which is slightly above the combined depth uncertainty related to the picking process and the resolution of the RES images. A lower-range resolution and signal-to-noise ratio in older RES data introduce bias into isochrone identification, and although distinct isochrones were chosen, a miscorrelation between IRHs recorded by different radar systems can not be entirely excluded. Moreover, the CReSIS profiles do not precisely intersect at GRIP and deviate from each other. The radar traces closest to GRIP are thus found at slightly different locations for the three RES images, which explains the higher discrepancy of radar layer depths.

The isochrone dating was conducted for each profile individually, and the obtained depths, ages and uncertainties were averaged over the three lines (Table 3). The deepest non-continuous layer which could be identified at EastGRIP is found at a depth of $2360 \pm 11 \mathrm{~m}$ and is estimated to be $72400 \pm 1306$ years old. The layer depths of the continuously traced IRHs range from $421 \pm 11$ to $2152 \pm 11 \mathrm{~m}$ at the EastGRIP location, corresponding to ages of $3498 \pm 94$ to $51920 \pm 1240$ years b2k. Reflectors $1-9$ were deposited during the Holocene. The remaining reflectors are found in ice from the Last Glacial Period from which reflector 10 and 11 can be attributed to the onset of the Younger Dryas and the Bølling-Allerød. The relation between the GRIP and EastGRIP depths of the traced IRHs fits well with the GICC05 timescale (Mojtabavi et al., 2020; Rasmussen et al., 2014), and the ages obtained from the two drill sites agree within the uncertainties. We note that the layer dating at EastGRIP consistently leads to younger ages than the dating at GRIP, which is a likely consequence of inaccuracies related to the transformation between ice-core and radar depths.

Due to computational reasons, we did not use all 16 layers for the Monte Carlo inversion but picked 10 isochrones with approximately equal vertical spacing and used the EastGRIP ages for our simulation of layer propagation. The layers used for the Monte Carlo simulation are indicated in bold in Table 3 and plotted with a consistent colour code in Figs. 4, 5 and 7 , representing the corresponding ages.

\subsection{Ice-flow model}

A full simulation of ice flow in the catchment area of the NEGIS is a highly under-determined problem (Keisling et al., 2014), lacking geophysical, climatic and ice-core data, some of which will become available in the future. Simpler models do not solve the problem in detail and are thus computationally much cheaper. Hence, limited but still useful information can be obtained from a simplified treatment of ice flow (e.g. Dansgaard and Johnsen, 1969; Dahl-Jensen et al., 2003; Waddington et al., 2007; Christianson et al., 2013; Keisling et al., 2014).

Here, we use a two-dimensional Dansgaard-Johnsen model (Dansgaard and Johnsen, 1969) to simulate the propagation and deformation of internal layers along approximated flow lines between the ice-sheet summit (GRIP) and EastGRIP. The simplicity of the model makes it well suited for the Monte Carlo method due to its few model parameters, the allowance for large time steps and it having an analytical solution (Grinsted and Dahl-Jensen, 2002). The model assumes ice incompressibility and a constant vertical strain rate down to the so-called kink height $(h)$ below which the strain rate decreases linearly. Basal sliding and melting are included in the model, and the ice-sheet thickness $(H)$ is assumed to be constant in time.

We consider a coordinate system where the $x$ axis points along the approximated flow line, the $y$ axis is horizontal and perpendicular to the flow line, and the $z$ axis indicates the height above the bed. The horizontal velocities parallel $\left(u_{\|}\right)$ and perpendicular $\left(u_{\perp}\right)$ to the profiles are described by Grinsted and Dahl-Jensen (2002) as

$u_{\|}(z)= \begin{cases}u_{\|, \text {sur }}(x, y)\left[\left(1-f_{\text {bed }}\right) \frac{z}{h}+f_{\text {bed }}\right], & z \in[0, h] \\ u_{\|, \text {sur }}(x, y), & z \in[h, H],\end{cases}$
$u_{\perp}(z)= \begin{cases}u_{\perp, \text { sur }}(x, y)\left[\left(1-f_{\text {bed }}\right) \frac{z}{h}+f_{\text {bed }}\right], & z \in[0, h] \\ u_{\perp, \text { sur }}(x, y), & z \in[h, H],\end{cases}$

where $u_{\| \text {, sur }}$ and $u_{\perp \text {,sur }}$ are the surface velocities parallel and perpendicular to the profile and the basal sliding factor $f_{\text {bed }}$ is the ratio between the ice velocity at the bed and at the surface.

Ice flow in the vicinity of an ice stream is affected by lateral compression and longitudinal extension, in particular across the shear margins of the NEGIS. We thus introduce $\alpha=\frac{\partial u_{\|}}{\partial x}+\frac{\partial u_{\perp}}{\partial y}$ as the sum of the horizontal strain rates. Due to ice incompressibility, we can write $\alpha+\frac{\partial \omega}{\partial z}=0$, where $\omega$ symbolizes the vertical velocity. The $x$ and $y$ dependency in Eqs. (6)-(7) only relates to the surface velocity such that $\alpha_{\text {sur }}$ represents the horizontal dependency in the equations and can be calculated from the ice surface velocities. 


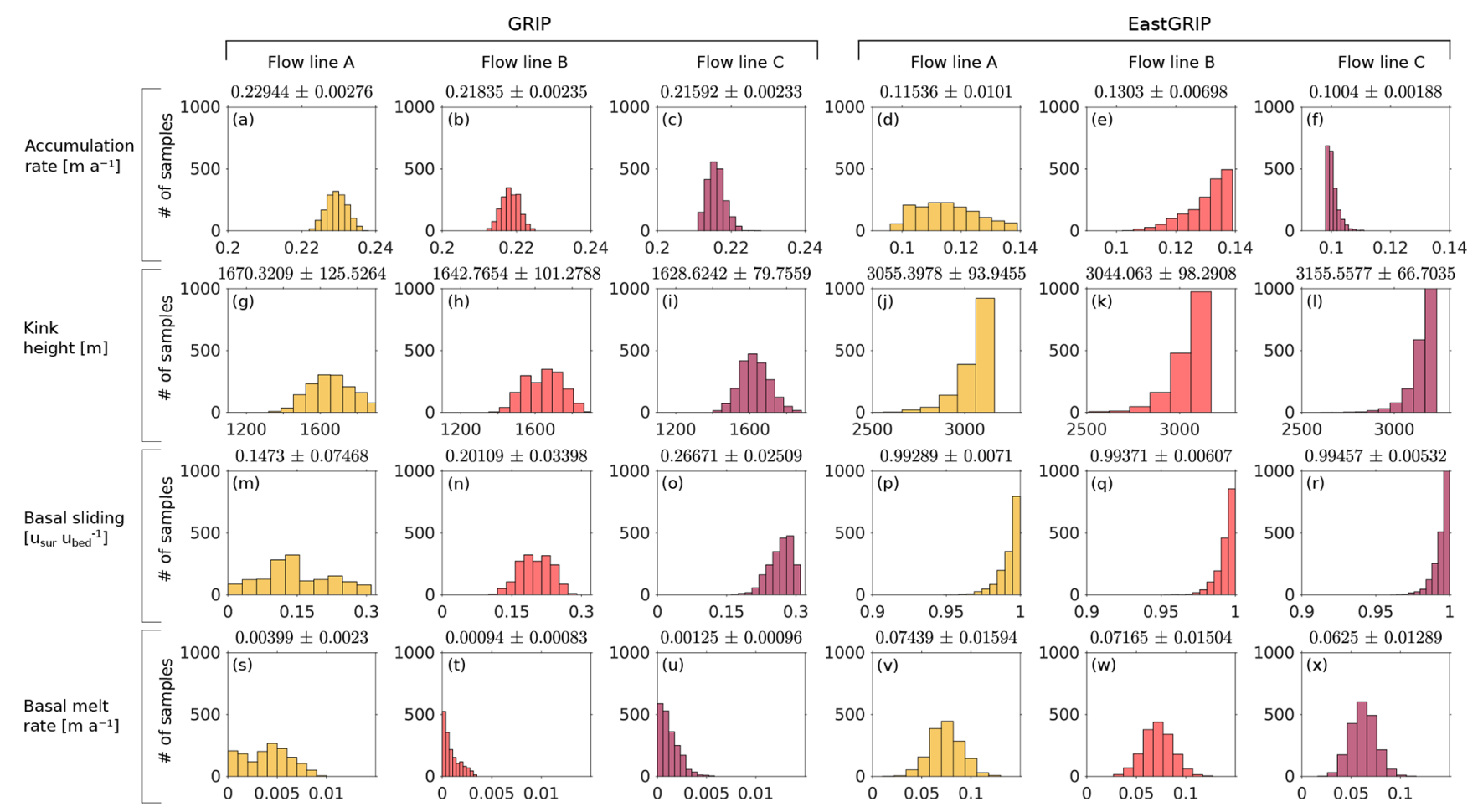

Figure 6. Histograms of the model parameters accumulation rate, basal melt rate, kink height and basal sliding at GRIP and EastGRIP for each flow line. The corresponding means and standard deviations are displayed on top of the histograms.

The vertical velocities $(\omega)$ are obtained through integration of the incompressibility relation $\omega(z)=-\int \alpha \mathrm{d} z$ (Dansgaard and Johnsen, 1969):

$\omega(z)= \begin{cases}\omega_{\text {bed }}-\alpha_{\text {sur }}\left(f_{\text {bed }} z+\frac{z^{2}}{2 h}\left(1-f_{\text {bed }}\right)\right) & z \in[0, h] \\ \omega_{\text {sur }}+\alpha_{\text {sur }}(H-z) & z \in[h, H] .\end{cases}$

The boundary conditions for the vertical velocity at the bed $\left(\omega_{\text {bed }}\right)$ and surface $\left(\omega_{\text {sur }}\right)$ are

$\omega_{\text {bed }}=-\dot{b}+f_{\text {bed }} u_{\text {sur }} \frac{\partial E_{\text {bed }}}{\partial x}$,

$\omega_{\text {sur }}=-\dot{a}+u_{\text {sur }} \frac{\partial E_{\text {sur }}}{\partial x}$,

where $\dot{b}$ is the positive basal melt rate; $\dot{a}$ is the positive accumulation rate; and $E_{\text {bed }}$ and $E_{\text {sur }}$ are the bed and surface elevations, respectively. From Eq. (8) we derive the following expression for the modelled $\alpha_{\text {sur }}$ :

$\alpha_{\text {sur }}=\frac{\omega_{\text {bed }}-\omega_{\text {sur }}}{H-\frac{h}{2}\left(1-f_{\text {bed }}\right)}$.

Following Grinsted and Dahl-Jensen (2002) and Buchardt and Dahl-Jensen (2007), we adjust the accumulation rates and surface velocities to the climate conditions of the corresponding time with a scaling factor $\xi(t)$ :

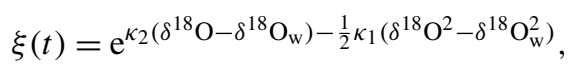

with $\kappa_{1}=\frac{c_{\mathrm{W}}-c_{\mathrm{c}}}{\delta^{18} \mathrm{O}_{\mathrm{w}}-\delta^{18} \mathrm{O}_{\mathrm{c}}}$ and $\kappa_{2}=c_{\mathrm{w}}-\delta^{18} \mathrm{O}_{\mathrm{w}} \kappa_{1}$.

We use the oxygen isotope $\delta^{18} \mathrm{O}$ record from NorthGRIP (Andersen et al., 2004) due to its high temporal resolution, and $\delta^{18} \mathrm{O}_{\mathrm{w}}=-35.2 \%$ and $\delta^{18} \mathrm{O}_{\mathrm{c}}=-42 \%$ are typical isotope values for warm interstadial and cold stadial periods, respectively. The parameters $c_{\mathrm{w}}$ and $c_{\mathrm{c}}$ determine the sensitivity of the accumulation rate with varying $\delta^{18} \mathrm{O}$ in warm $\left(c_{\mathrm{W}}\right)$ and cold $\left(c_{\mathrm{c}}\right)$ periods and are defined as follows (Grinsted and Dahl-Jensen, 2002; Buchardt and Dahl-Jensen, 2007):

$c_{\mathrm{w}}=\left.\frac{1}{\dot{a}} \frac{\partial \dot{a}}{\partial \delta^{18} \mathrm{O}}\right|_{\delta^{18} \mathrm{O}=\delta^{18} \mathrm{O}_{\mathrm{w}}}, c_{\mathrm{c}}=\left.\frac{1}{\dot{a}} \frac{\partial \dot{a}}{\partial \delta^{18} \mathrm{O}}\right|_{\delta^{18} \mathrm{O}=\delta^{18} \mathrm{O}_{\mathrm{c}}}$.

To simulate the propagation of ice particles deposited at the surface of the GrIS, Eqs. (6) and (8) are solved at a time interval of 10 years.

\subsection{Monte Carlo sampling}

The ice-flow parameters $\dot{a}, h, f_{\text {bed }}$ and $\dot{b}$ are defined for intervals of $\sim 10 \mathrm{~km}$ along the flow lines and form together with the two climate scaling factors, $c_{\mathrm{c}}$ and $c_{\mathrm{w}}$, the model vector $\boldsymbol{m}$. This results in a total of 170 (flow line A and B) and 194 (flow line C) model parameters. Each combination of them represents a possible solution to the inverse problem $\boldsymbol{d}=g(\boldsymbol{m})$, where $g(\boldsymbol{m})$ represents the ice-flow model described in the previous section. The data vector $\boldsymbol{d}$ contains the 

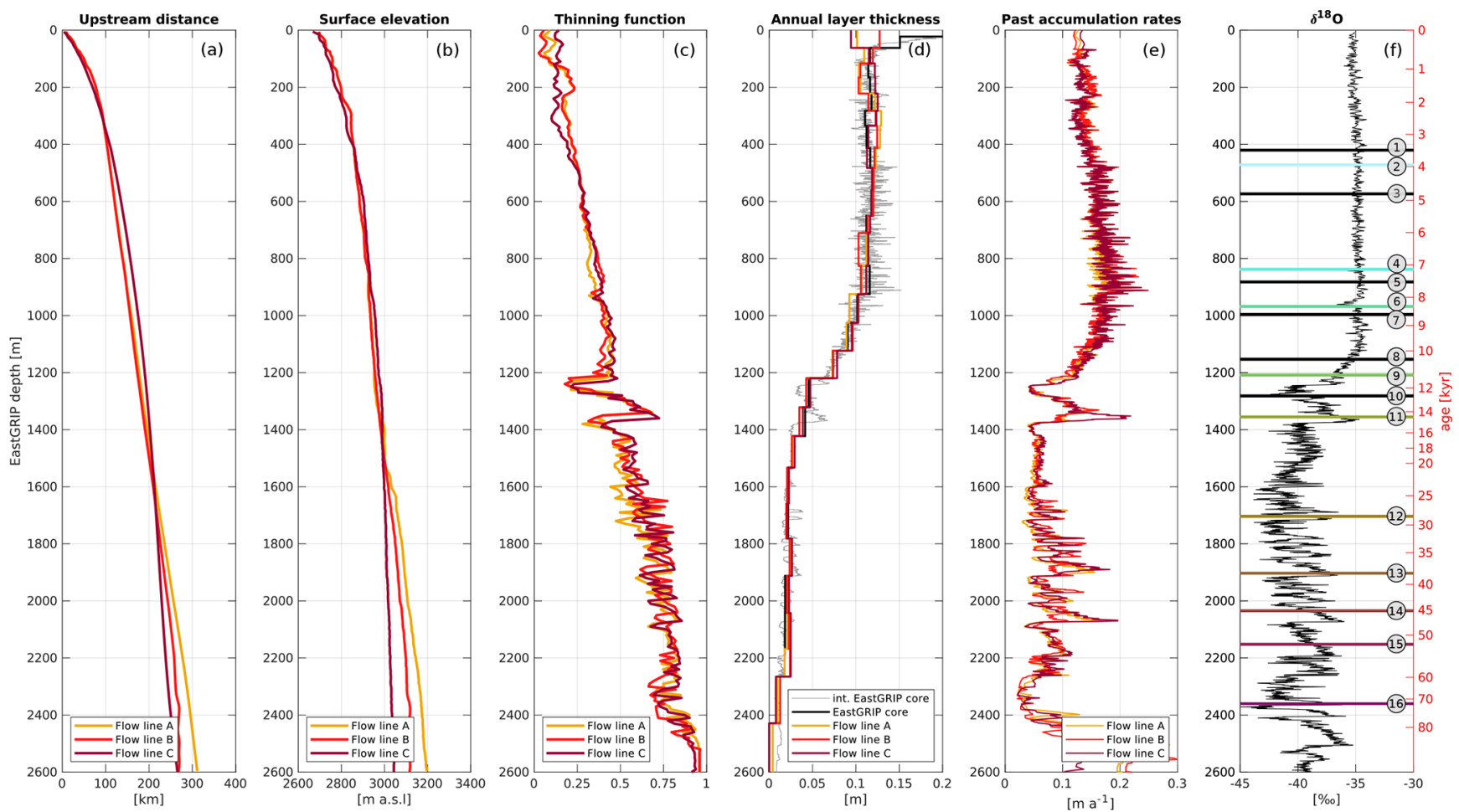

Figure 7. Modelled upstream distance (a) and surface elevation (b) of the source location for ice in the EastGRIP ice core. The thinning function (c) was calculated from the modelled accumulation rates and annual layer thicknesses (d) and was combined with the interpolated annual layer thicknesses observed in the ice core (d) to calculate past accumulation rates in high resolution (e). The $\delta^{18} \mathrm{O}$ curve from NorthGRIP (f) was scaled to the EastGRIP depths to put the results into a climatic context. The depths of the traced isochrones from Table 3 are displayed with the same colour index as in Figs. 4 and 5 and labelled with the corresponding layer number.

isochrone depths and $\alpha_{\text {sur }}$ determined from the MEaSUREs Multi-year v1 surface velocities (Joughin et al., 2018) at a resolution of $1 \mathrm{~km}$.

Like in most geophysical inverse problems, many different combinations of model parameters can explain the observed data equally well within the range of their uncertainties, and therefore, a non-unique solution does not exist. Probabilistic inverse methods consider many different models and describe them in terms of their plausibility, rather than finding one possible solution. This makes these methods particularly well suited for nonlinear problems, where the probability density in the model space typically shows multiple maxima (Mosegaard and Tarantola, 1995).

Monte Carlo methods are based on a random number generator which allows the sampling according to the target probability distribution in an efficient way. The grey box in Fig. 2 illustrates the iterative sampling process of the Metropolis algorithm (Metropolis et al., 1953) used here: starting from an initial model $\left(\boldsymbol{m}_{0}\right)$, a random walker explores the model space and proposes new models $\left(\boldsymbol{m}_{\text {new }}\right)$ which are accepted with a certain probability $\left(P_{\text {accept }}\right)$. This way of importance sampling avoids unnecessary evaluation of model parameters in low-probability areas (Mosegaard, 1998).
To estimate the initial accumulation rate $\dot{a}_{0}$, we integrate Eq. (8) (see Appendix B) and obtain the following depth-age relationship

$(H-z)=\frac{\dot{a}}{\alpha_{\text {sur }}}\left(1-\mathrm{e}^{-\alpha_{\text {sur }} t}\right)$,

where $t$ and $z$ represent the isochrone age and height above the bed, respectively. The accumulation rate $\dot{a}$ is determined with a curve-fitting function, using at least five isochrones younger than $10 \mathrm{kyr}$ at each point along the flow line. The initial kink height $\left(h_{0}\right)$, basal sliding $\left(f_{\text {bed, } 0}\right)$ and basal melt rate $\left(\dot{b}_{0}\right)$ are scaled with the normalized surface velocity $\left(\hat{u}_{\text {sur }}\right)$ as follows:

$h_{0}=H\left(\frac{1}{2}-e_{1} \hat{u}_{\text {sur }}\right)$,

$f_{\text {bed, } 0}=e_{2} \hat{u}_{\text {sur }}$,

$\dot{b}_{0}=e_{3} \hat{u}_{\text {sur }}$,

where $e_{1}=0.4, e_{2}=0.8$ and $e_{3}=0.03$ and the initial value for $c_{\mathrm{W}}$ and $c_{\mathrm{c}}$ is assumed to be 0.15 and 0.10 , respectively. In each iteration a new model $\boldsymbol{m}_{\text {new }}$ is proposed as

$\boldsymbol{m}_{\text {new }}=\boldsymbol{m}_{0}+\boldsymbol{q} \boldsymbol{A}$, 
where $\boldsymbol{m}_{0}$ is the initial model and $\boldsymbol{A}$ contains the perturbation amplitude of the corresponding model parameters. The vector $\boldsymbol{q}$ defines the random walk in the multidimensional model space and solely depends on the preceding step. In each iteration, $i$, one model parameter, $j$, is randomly selected and perturbed as

$\boldsymbol{q}_{i+1}(j)=\boldsymbol{q}_{i}(j)+\left(r-\frac{1}{2}\right) \boldsymbol{p}(j)$,

where $r$ indicates a random number between 0 and 1 and $p$ regulates the maximum step length per iteration of the selected parameter type. To achieve a good performance of the Monte Carlo algorithm, the values of $\boldsymbol{A}$ and $\boldsymbol{p}$ (shown in Table 4) are chosen such that the acceptance ratio for the individual model parameters lies between $25 \%$ and $75 \%$.

The quality of the proposed model is evaluated by the function $S(\boldsymbol{m})$ which describes the misfit between the modelled and observed data (see Appendix $C$ ). The new model $\left(\boldsymbol{m}_{\text {new }}\right)$ is accepted with the acceptance probability (Metropolis et al., 1953)

$P_{\text {accept }}=\min \left(\frac{L\left(\boldsymbol{m}_{\text {new }}\right)}{L\left(\boldsymbol{m}_{\text {old }}\right)}, 1\right)$,

where $\boldsymbol{m}_{\text {old }}$ is the last accepted model and the likelihood function is defined as $L(\boldsymbol{m})=\mathrm{e}^{-S(\boldsymbol{m})}$.

To ensure that parameter sampling is occurring in a physically reasonable range, the a priori probability distribution is assumed to be uniform within the following intervals:

$\dot{a} \in\left[\dot{a}_{0}-0.02 \mathrm{ma}^{-1}, \dot{a}_{0}+0.02 \mathrm{ma}^{-1}\right]$,

$h \in[0, H]$,

$f_{\text {bed }} \in\left[\max \left(0, f_{\text {bed, } 0}-0.3\right), \min \left(1, f_{\text {bed }, 0}+0.3\right)\right]$,

$\dot{b} \in\left[0,0.2 \mathrm{ma}^{-1}\right]$.

The sampling intervals are based on expected values of the corresponding parameter: the initial accumulation rate obtained from the radar stratigraphy is considered quite trustworthy, but because the local layer approximation is not justified in the survey area (Waddington et al., 2007) we allow the accumulation rate to deviate by $0.02 \mathrm{ma}^{-1}$. The kink height is limited to the ice-sheet thickness; the basal sliding fraction is allowed to deviate by $30 \%$ from the initial model, and the upper limit of the basal melt rate is based on values suggested at EastGRIP by a recent study (Zeising and Humbert, 2021).

In their initial phase, Markov chain Monte Carlo methods move from the starting model towards a high-probability area where the target distribution is sampled. To avoid sampling during this so-called burn-in phase, the first $1 \times 10^{6}$ accepted models are discarded. Since only one parameter is perturbed at a time, successive models are highly correlated. To obtain a distribution of independent models, only every 1000th accepted model is saved. The sampling is continued for $6 \times 10^{6}$ iterations in total.
Table 4. Perturbation amplitude $(A)$ and step length $(p)$ of the individual model parameters used for the Monte Carlo sampling. The sampling parameters were chosen such that the acceptance ratio of the individual model parameters lies between $25 \%$ and $75 \%$.

\begin{tabular}{lrr}
\hline Model parameter & Amplitude $(A)$ & Step length $(p)$ \\
\hline$\dot{a}$ & $0.01 \mathrm{~m} \mathrm{a}^{-1}$ & 0.5 \\
$\dot{b}$ & $0.01 \mathrm{~m} \mathrm{a}^{-1}$ & 1 \\
$h$ & $100 \mathrm{~m}$ & 3 \\
$f_{\text {bed }}$ & 0.05 & 2 \\
$c_{\mathrm{c}}$ & 0.05 & 0.5 \\
$c_{\mathrm{W}}$ & 0.05 & 0.5 \\
\hline
\end{tabular}

\section{Results}

\subsection{Model parameters}

Due to the mixed determined nature of the inverse problem addressed in this study, a unique solution of model parameters does not exist. The Monte Carlo sampling results in a number of possible models distributed according to the posterior probability. Here, we present the mean model parameters with the standard deviations of the posterior probability distribution and emphasize that the corresponding histograms (Fig. 6) are essential to understanding the uncertainties in the parameter considered.

The flow-line characteristics and model parameters for each flow line are summarized in Fig. 4. The radar profiles with the observed and modelled isochrones are displayed as a function of the distance from the EastGRIP ice-core location. Particle trajectories were calculated from the simulated velocity field with the mean model parameters and indicate the source location of ice found at the modelled isochrone depth in the EastGRIP ice core. The isochrones and particle trajectories are illustrated with the same colour code as in Figs. 5 and $7 f$, indicating the corresponding age. The horizontal strain rates $\left(\dot{\varepsilon}_{x x}, \dot{\varepsilon}_{y y}\right.$ and $\left.\dot{\varepsilon}_{x y}\right)$ were obtained from the MEaSUREs Multi-year v1 surface velocity components (Joughin et al., 2018) parallel $\left(u_{\|}\right)$and perpendicular $\left(u_{\perp}\right)$ to the approximated flow line. The strain rates show mostly low, positive values along the flow lines with the exception of the shear-margin crossing in profile $\mathrm{A}$ and $\mathrm{B}$, which is characterized by longitudinal extension and lateral compression.

The central observed features are the following:

1. The accumulation rate decreases with increasing distance from the central ice divide. In flow line A and B, it remains almost constant between -220 and $-80 \mathrm{~km}$, followed by a drop of about $20 \%$ across the shear margins. In the first $\sim 150 \mathrm{~km}$ of flow line $\mathrm{C}$, which corresponds to the ice divide, the accumulation rate remains nearly constant, followed by a gradual decrease with increasing distance along the profile. 
2. The kink height fluctuates around the middle of the ice column in the vicinity of the ice ridge and is drawn closer to the bed in the centre of the profiles. Locally very high kink heights are observed in flow line A around -230 and $-150 \mathrm{~km}$, in flow line B at -240 and $-140 \mathrm{~km}$, and at $-100 \mathrm{~km}$ in flow line C. In all profiles, $h$ increases substantially at about $-60 \mathrm{~km}$.

3. The basal velocity ranges between $0 \%$ and $50 \%$ of the surface velocity outside the NEGIS and increases to $60 \%-100 \%$ in the vicinity of EastGRIP.

4. The basal melt rate at the beginning of the profiles varies between 0 and $0.03 \mathrm{~m} \mathrm{a}^{-1}$. As for the kink height, flow line A shows strong melt rate fluctuations in the centre of the profile, some of which are also observed in flow line B. At EastGRIP, basal melt rates of between 0.05 and $0.1 \mathrm{ma}^{-1}$ are obtained, but higher values of up to $0.2 \mathrm{~m} \mathrm{a}^{-1}$ are reached further downstream.

\subsection{Monte Carlo performance}

The comparison of modelled and observed isochrones (Fig. 5a, c, e) and $\alpha_{\text {sur }}$ (Fig. S2 in the Supplement) shows a good fit in most parts of the flow lines. However, our model is not able to accurately reproduce strong internal layer undulations which are not related to the bed topography or the surface conditions, resulting in a larger misfit where such undulations are present (Fig. 5b, d, f). In general, the isochrone misfit tends to be larger for deeper layers. Particularly distinct is the positive misfit at EastGRIP for the deepest layer in all profiles, indicating that the depths of old layers are overestimated. The average isochrone misfit for flow line A, B and $\mathrm{C}$ is $2.94 \%, 2.34 \%$ and $1.49 \%$ of the respective layer depth.

Histograms in Fig. 6 show the sampled probability distribution of model parameters at GRIP and EastGRIP with the corresponding mean and standard deviation displayed on top. Distributions with distinctive single peaks and low standard deviations point towards a good parameter resolution, while multiple maxima or large standard deviations indicate that several models are found to be equally likely. The parameter resolution is in general better at the beginning of the profiles, most clearly represented by the narrow distributions in the accumulation rate, basal melt rate and kink height at GRIP. Exponential distributions imply that a parameter reaches regularization boundaries. This is the case for the basal melt rates at GRIP, the kink height and basal sliding factor at EastGRIP, and the accumulation rate in flow line B and $\mathrm{C}$ at EastGRIP. The climate parameter $c_{\mathrm{W}}$ is found to be $0.10 \pm 0.005$ for all flow lines. The obtained value for parameter $c_{\mathrm{c}}$ is $0.14 \pm 0.003$ for flow line A and B and $0.16 \pm 0.004$ for flow line C. The histograms of $c_{\mathrm{w}}$ and $c_{\mathrm{c}}$ can be found in Fig. S3 in the Supplement.

\subsection{Ice origin and ice-flow history}

From the modelled velocity field, we calculate particle trajectories backwards in time (Fig. 4) which give insight into the source location and flow history of ice found at a certain depth in the EastGRIP ice core and allow us to determine the accumulation rate during its deposition (Fig. 7e). Due to the higher velocities in the ice stream, the ice source location in the upper $1600 \mathrm{~m}$ of the ice core lies further upstream for flow line C compared to flow line A and B. For deeper ice, this trend is reversed, as the velocity along flow line $\mathrm{C}$ drops below the velocity of line A and B (Fig. 7a). A similar effect manifests itself in the upstream elevation, where higher velocities along flow line $\mathrm{C}$ result in higher elevations in the upper part of the ice column, which is compensated for by a flatter topographic profile for ice deeper than $1400 \mathrm{~m}$ (Fig. 7b).

From the model-inferred in situ accumulation rates, $\dot{a}_{\mathrm{m}}$, and annual layer thicknesses, $\lambda_{\mathrm{m}}$, we calculate the ice-core thinning function $\gamma$ :

$\gamma=\frac{\dot{a}_{\mathrm{m}}-\lambda_{\mathrm{m}}}{\dot{a}_{\mathrm{m}}}$.

The thinning function increases nearly linearly with depth in the Holocene and shows a considerable decrease in the Younger Dryas and enhanced thinning in the BøllingAllerød. In the glacial part of the ice core, the thinning function fluctuates between interstadials and stadials. The shift between the three lines results from the slightly different depth-age relationships and isochrone misfits obtained from the three profiles. We combine the thinning function with the annual layer thicknesses observed in the EastGRIP ice core, $\lambda_{\text {obs }}$, to estimate past accumulation rates, $\dot{a}_{\text {past }}$ :

$\dot{a}_{\text {past }}=\frac{\lambda_{\text {obs }}}{1-\gamma}$.

We find that the accumulation rate at the deposition site increases from $\sim 0.12 \mathrm{~m} \mathrm{a}^{-1}$ to a maximum of $0.249 \mathrm{~m} \mathrm{a}^{-1}$ for ice at a depth of $912 \mathrm{~m}$, which was deposited approximately 7800 years b2k. We note that the constant annual layer thicknesses observed in the upper $900 \mathrm{~m}$ of the EastGRIP ice core (Mojtabavi et al., 2020) coincide with the spatial pattern of increasing accumulation along the flow line with increasing upstream distance (Figs. 4c, g, k and 7d, e). Ice between 900 and $1400 \mathrm{~m}$ is characterized by the transition from the Holocene into the Last Glacial Period with decreased accumulation rates in the Younger Dryas and a peak during the Bølling-Allerød (Fig. 7e). The accumulation rate at the deposition site for older ice varies between $0.02 \mathrm{~m} \mathrm{a}^{-1}$ during stadials and $0.196 \mathrm{~m} \mathrm{a}^{-1}$ during interstadials. The atmosphere in the glacial period was in general colder and dryer, and hence, accumulation rates were typically lower than today (Cuffey and Clow, 1997). However, due to the upstream flow effects, the ice from the interstadials could have been deposited under 
Table 5. Essential quantities for upstream corrections for selected depths of the EastGRIP ice core. The upstream distance, elevation and past accumulation rates $\dot{a}_{\text {past }}$ describe the characteristics of the source location and the conditions during ice deposition. $\dot{a}_{\text {present }}$ represents the corresponding present-day accumulation rates at the source location. All quantities are averages over the three flow lines, and the uncertainties represent the maximum deviation from the mean.

\begin{tabular}{|c|c|c|c|c|c|c|}
\hline $\begin{array}{l}\text { Depth } \\
{[\mathrm{m}]}\end{array}$ & $\begin{array}{r}\text { Age } \\
\text { [years b2k] }\end{array}$ & $\begin{array}{r}\text { Upstream distance } \\
{[\mathrm{km}]}\end{array}$ & $\begin{array}{r}\text { Elevation } \\
\text { [ma.s.1.] }\end{array}$ & Thinning function & $\begin{array}{r}\dot{a}_{\text {past }} \\
{\left[\mathrm{ma}^{-1}\right]}\end{array}$ & $\begin{array}{l}\dot{a}_{\text {present }} \\
{\left[\mathrm{ma}^{-1}\right]}\end{array}$ \\
\hline 100 & 665 & $47 \pm 3$ & $2752 \pm 10$ & $0.10 \pm 0.03$ & $0.12 \pm 0.004$ & $0.12 \pm 0.015$ \\
\hline 200 & 1553 & $74 \pm 2$ & $2788 \pm 11$ & $0.19 \pm 0.08$ & $0.14 \pm 0.006$ & $0.14 \pm 0.005$ \\
\hline 300 & 2418 & $92 \pm 1$ & $2837 \pm 14$ & $0.16 \pm 0.05$ & $0.13 \pm 0.005$ & $0.15 \pm 0.010$ \\
\hline 400 & 3322 & $105 \pm 7$ & $2854 \pm 6$ & $0.21 \pm 0.02$ & $0.14 \pm 0.002$ & $0.14 \pm 0.031$ \\
\hline 600 & 5037 & $126 \pm 12$ & $2892 \pm 14$ & $0.28 \pm 0.00$ & $0.16 \pm 0.001$ & $0.16 \pm 0.005$ \\
\hline 800 & 6805 & $146 \pm 14$ & $2920 \pm 9$ & $0.35 \pm 0.03$ & $0.15 \pm 0.005$ & $0.16 \pm 0.003$ \\
\hline 1000 & 8640 & $165 \pm 13$ & $2944 \pm 15$ & $0.42 \pm 0.03$ & $0.16 \pm 0.004$ & $0.17 \pm 0.002$ \\
\hline 1200 & 11015 & $183 \pm 12$ & $2965 \pm 19$ & $0.41 \pm 0.06$ & $0.12 \pm 0.010$ & $0.17 \pm 0.005$ \\
\hline 1400 & 15571 & $200 \pm 7$ & $2993 \pm 7$ & $0.46 \pm 0.01$ & $0.05 \pm 0.001$ & $0.17 \pm 0.015$ \\
\hline 1600 & 23382 & $217 \pm 3$ & $3027 \pm 26$ & $0.52 \pm 0.08$ & $0.05 \pm 0.007$ & $0.18 \pm 0.023$ \\
\hline 1800 & 33524 & $234 \pm 8$ & $3054 \pm 40$ & $0.72 \pm 0.06$ & $0.11 \pm 0.028$ & $0.19 \pm 0.021$ \\
\hline 2000 & 43107 & $252 \pm 14$ & $3079 \pm 54$ & $0.73 \pm 0.07$ & $0.10 \pm 0.019$ & $0.19 \pm 0.022$ \\
\hline 2200 & 54864 & $271 \pm 19$ & $3108 \pm 73$ & $0.83 \pm 0.02$ & $0.07 \pm 0.006$ & $0.19 \pm 0.030$ \\
\hline 2400 & 75980 & $293 \pm 18$ & $3136 \pm 80$ & $0.83 \pm 0.11$ & $0.08 \pm 0.034$ & $0.19 \pm 0.023$ \\
\hline 2600 & 94696 & $322 \pm 12$ & $3171 \pm 67$ & $0.94 \pm 0.03$ & $0.18 \pm 0.044$ & $0.20 \pm 0.005$ \\
\hline
\end{tabular}

higher accumulation rates than are observed at the EastGRIP site today.

The variations in the past accumulation-rate between the three flow lines result from both the varying along-flow accumulation pattern and different upstream distances of the source location. The spread between the three models provides important uncertainty estimates. The average deviation from the mean accumulation rates is $3.9 \%$ in the Holocene and $20 \%$ in the Last Glacial Period. The largest spread between the three flow lines is $68 \%$ observed at a depth of $2411 \mathrm{~m}$. We remark that, due to missing direct information on the annual layer thicknesses, accumulation rates below the current borehole depth of $2122.45 \mathrm{~m}$ are based on tentative estimates and must be treated accordingly.

\section{Discussion}

\subsection{Isochrone deformation and ice-flow parameters}

Deformation of IRHs occurs as a consequence of bed topography (Robin and Millar, 1982; Jacobel et al., 1993), spatial variations in basal conditions (Weertman, 1976; Whillans, 1976; Whillans and Johnsen, 1983; Catania et al., 2010; Christianson et al., 2013; Leysinger Vieli et al., 2018; Wolovick et al., 2014), spatially varying accumulation rates and corresponding changes in ice-flow geometry (Dansgaard and Johnsen, 1969; Weertman, 1976; Whillans, 1976; Whillans and Johnsen, 1983), and convergent ice flow and ice-stream activity (Bons et al., 2016). Areas of enhanced basal melt rates similarly drag down all the layers above, while variations in accumulation rate, kink height and basal sliding lead to depth-dependent deformation of the isochrones (Keisling et al., 2014).

The accumulation rates of $\sim 0.21-0.23 \mathrm{~m} \mathrm{a}^{-1}$ at GRIP and $\sim 0.1-0.13 \mathrm{ma}^{-1}$ at EastGRIP obtained in this study agree with field observations (Dahl-Jensen et al., 1993; Vallelonga et al., 2014), and the low standard deviations point towards a robust solution. In profiles A and B we observe $\sim 20 \%$ lower accumulation rates inside the ice stream than outside. This agrees to some extent with Riverman et al. (2019), who found $20 \%$ higher accumulation rates in the shear margins compared to the surroundings, although our observations are not confined to the shear margins only. Regularization on the accumulation rate was necessary in our model to avoid unrealistically strong fluctuations along the flow lines.

The bed topography and bed lubrication have a considerable effect on ice-flow parameters. Flow over bed undulations affects the elevation of internal layers due to variations in the longitudinal stresses within the ice (Hvidberg et al., 1997 ) and is often reflected in the surface topography (Cuffey and Paterson, 2010). If the bed is "sticky", i.e. the basal sliding is small, the ice is compressed along the flow direction while vertically extended (Weertman, 1976) and IRHs are pushed upwards. At a slippery bed, the opposite is the case, resulting in along-flow extension of IRHs which leads to thinning and thus decreasing distance between the IRHs. Keisling et al. (2014) argued that major fold trains existing independently of bed undulations can be explained by variations in the basal sliding conditions. This is, for instance, observed across shear margins, where local, steady-state folds are formed as a response to the basal conditions (Keisling et al., 2014; Holschuh et al., 2014). In flow line A, we ob- 
serve similar "fold trains" on a larger scale downstream of a substantial bed undulation (100-200 km upstream of EastGRIP), and the resulting high basal melt rates and sliding fraction and the low kink heights drag the layers down in the attempt to match the observed synclines. These strongly deformed isochrones predominantly appear in parts of the flow lines which deviate from the observed surface velocity direction by more than $15^{\circ}$. We thus argue that they are out-ofthe-plane effects and that the isochrones along the ice-flow direction are less strongly deformed. Accordingly, it is questionable whether the ice in the EastGRIP ice core has experienced such deformation and whether the high local basal melt rates are trustworthy. The fact that these folds are not reproduced very well by the model does therefore not put any constraints on the usefulness of our results for upstream corrections.

The NEGIS differs from other ice streams in Greenland and Antarctica through the lack of clear lateral topographic constraints and high ice-flow velocities reaching exceptionally far inland. The positioning of the shear margins of the NEGIS is most likely strongly interconnected to the subglacial water system and the substrate and morphology of the bed (Christianson et al., 2014; Franke et al., 2021a). The vast amount of ice mass is added to the NEGIS by entering the ice stream through the shear margins (Franke et al., 2021a), resulting in a compressional stress regime perpendicular to the ice stream. The sudden increase in the kink height at around $60 \mathrm{~km}$ upstream of EastGRIP pushes the isochrones upwards, similarly to the effect of lateral compression. The distribution of available meltwater and a soft, deformable bed facilitate sliding and, thus, ice-flow acceleration at the NEGIS onset (Christianson et al., 2014). Evidence of a locally enhanced geothermal heat flux and basal ice at the melting point has been presented by, for example, Fahnestock et al. (2001) and MacGregor et al. (2016), and bed lubrication through meltwater production seems to be one of the driving mechanisms for rapid ice flow in the onset region of the NEGIS (SmithJohnsen et al., 2020b). Our results support these previous findings in the following way: (1) kink heights close to the bed in large segments along the flow profiles imply that most shear deformation is happening in the lower part of the ice column or at the ice-bed interface. The increased kink height towards the ends of the profiles can be attributed to the compressional stress regime associated with the addition of ice through the shear margins. (2) Basal melt rates of $0.01 \mathrm{ma}^{-1}$ or higher inside the NEGIS suggest that the basal ice temperatures along the flow lines are at the pressure melting point and enough energy is available to produce meltwater leading to substantial bed lubrication. (3) Basal sliding is present in most segments of the flow lines, suggesting the presence of meltwater or deformation of a soft bed. It increases considerably along the flow lines and significantly contributes to the surface velocity at EastGRIP.

While it is commonly accepted that the NEGIS is initiated by a locally enhanced geothermal heat flux (e.g. Fahnestock et al., 2001; Alley et al., 2019), the magnitude thereof and the resulting hydrological conditions of the bed are still highly debated. Previous studies using simple strain-rate models in combination with Holocene radar stratigraphy indicate basal melt rates of $0.1 \mathrm{ma}^{-1}$ or higher in the vicinity of EastGRIP (Fahnestock et al., 2001; Keisling et al., 2014; MacGregor et al., 2016). However, the accuracy of these findings is limited since the local layer approximation (Waddington et al., 2007) is not valid in the surrounding of the NEGIS (Keisling et al., 2014; MacGregor et al., 2016). Remarkably high basal melt rates of $0.16-0.22 \mathrm{ma}^{-1}$ are also suggested by a recent study (Zeising and Humbert, 2021) using an autonomous phase-sensitive radio-echo sounder (ApRES) at EastGRIP. Melt rates on these orders of magnitude would require either an unusually high geothermal heat flux exceeding the continental background (Fahnestock et al., 2001; Bons et al., 2021) or an additional heat source (Zeising and Humbert, 2021). Alley et al. (2019) discussed the interactions between the GrIS and the geothermal anomaly, presumably caused by the passage of Greenland over the Iceland hot spot (Lawver and Müller, 1994), and hypothesized that an exceptionally unsteady and inhomogeneous geothermal heat flux underneath northeast Greenland could arise through perturbations of the mantle stress regime caused by ice-sheet fluctuations.

Our results indicate basal melt rates at EastGRIP of between 0.05 and $0.1 \mathrm{ma}^{-1}$, but higher values of up to $0.2 \mathrm{ma}^{-1}$ are obtained further downstream. However, the depth of the oldest modelled isochrone tends to be overestimated in this part of the flow lines (Fig. 5), indicating that the basal melt rate is overestimated. Ice-flow parameters at a certain location affect the isochrones directly above and further downstream, and since EastGRIP is near the end of the radar lines, the information constraining the isochrone depths is limited, leading to an overall lower parameter resolution than further upstream.

\subsection{EastGRIP source location and upstream effects}

The source region of ice in the EastGRIP ice core extends over more than $300 \mathrm{~km}$ upstream. Holocene ice characterizes the upper $1244 \mathrm{~m}$ of the ice core and has been advected up to $197 \mathrm{~km}$. The climatic conditions during the last $8 \mathrm{kyr}$ have remained nearly constant with similar accumulation rates to today. However, due to increasing precipitation towards the central ice divide, ice from the past $8 \mathrm{kyr}$ was deposited under increasingly higher accumulation rates with increasing age (Table 5). Our results indicate that this upstream effect happens to compensate for the vertical layer thinning and results in the constant annual layer thicknesses observed in the upper $900 \mathrm{~m}$ of the EastGRIP ice core (Mojtabavi et al., 2020). One possible conclusion of this peculiar observation is that snow depositions must have been advected from far enough upstream to allow the compensation for vertical thinning by increased accumulation rates in the source location. This gives support to the hypothesis that ice-flow velocities 
in the past $8 \mathrm{kyr}$ must have been similarly fast to those today and that, therefore, the NEGIS has likely been active during this time. However, we believe that RES images and estimates of present-day accumulation rates along the EastGRIP flow line are necessary to evaluate this hypothesis further.

Between $8 \mathrm{kyr}$ b2k and the beginning of the Holocene, accumulation rates decreased at the deposition site due to progressively colder and dryer climatic conditions (Cuffey and Clow, 1997) as we go further back in time and transition into the GS-1. The most recent glacial period extends from 119140 to 11703 years b2k (Walker et al., 2009) and is characterized by Dansgaard-Oeschger events, abrupt transitions between cold stadial and relatively mild interstadial periods (Dansgaard et al., 1982; Johnsen et al., 1992) causing the oscillations in the accumulation rates. Ice from the Last Glacial Period was deposited between 197 and $332 \mathrm{~km}$ upstream from EastGRIP. The basal ice at EastGRIP could be more than $100 \mathrm{kyr}$ old which, according to our models, has been deposited within about $50 \mathrm{~km}$ from the ice divide under conditions similar to those at NorthGRIP and GRIP.

Ice that is entering the NEGIS must somehow penetrate the shear margin, which is an important characteristic of ice flow in ice streams and might have left an imprint on the crystal fabric and texture of ice extracted at EastGRIP. Our modelling results along flow line A and B indicate that ice below $239 \mathrm{~m}$ in the EastGRIP ice core passed the shear margin $82 \mathrm{~km}$ from EastGRIP at around $1.8 \mathrm{kyrb} 2 \mathrm{k}$. Slightly enhanced annual layer thicknesses observed in the ice core at a depth of $230 \mathrm{~m}$ (Fig. 3) seem unrelated to short-term warmer and wetter climate and might thus be an effect of enhanced accumulation across the shear margin, supporting our results.

Our results show surface elevations at the deposition site which are up to $500 \mathrm{~m}$ higher than EastGRIP at the corresponding time. Assuming a normal thermal and pressure gradient, this implies that ice was deposited under up to $\sim 3.25^{\circ} \mathrm{C}$ colder temperatures and up to $45 \mathrm{hPa}$ lower pressure than conditions found at the borehole location at the time of deposition.

\subsection{Limitations}

The most relevant limitation of this study arises from lacking radar data parallel to the flow field in the upstream area of EastGRIP. The approximated flow lines deviate from the present-day surface flow field in some parts by more than $15^{\circ}$, which presumably introduces out-of-the-plane effects. Data gaps encumbered isochrone tracing and restricted the Monte Carlo method due to missing information in those areas. The correlated parameters in the Dansgaard-Johnsen model lead to a vast number of possible solutions, and the fact that the observed data can be reproduced by our model does not prove the validity of the assumed parameters and the physical interpretation thereof. This becomes for instance evident at the GRIP ice-core site, where our results indicate basal sliding of up to $30 \%$, while the drilling project showed that the bed is frozen at the ice-sheet summit (Dahl-Jensen et al., 1998). The apparent basal sliding might thus represent deformation within a soft bed material rather than actual sliding of the ice over the bed. The spatial and formal resolution of the obtained model parameters is limited, in particular towards the end of the profiles due to limited constraining information further downstream.

By introducing the parameter $\alpha$, our model accounts for lateral compression and extension on a first-degree order but does not capture the full complexity of the flow field across the shear margins. While these play an essential role in the ice-flow dynamics of the NEGIS (Holschuh et al., 2019) and are likely to have left an imprint on the ice found in the EastGRIP ice core, the full simulation of the flow field is not attempted for the purpose of upstream corrections. This would require more complex 3D numerical ice-flow models which are computationally more expensive and thus not suitable for the Monte Carlo method applied here. Moreover, due to the lack of constraining radar data, the information gain in terms of the source characteristics and upstream effects of such a $3 \mathrm{D}$ model would be modest.

The elevation of the source location was determined solely from the present-day ice-sheet surface elevation and did not take into account past fluctuations in the ice-sheet thickness. In general, surface elevation changes are relatively minor in the interior areas of central Greenland (Marshall and Cuffey, 2000; Letréguilly et al., 1991). Yet, Vinther et al. (2009) found that the GRIP elevation might have been up to $200 \mathrm{~m}$ higher during the early Holocene than today. We did not take into account changes in the ice thickness due to the large uncertainties which would be introduced, particularly in the Last Glacial Period. Our estimates of the surface elevation of the source location must thus not be interpreted as absolute values but rather as relative changes with respect to the surface elevation of the EastGRIP site at the corresponding time.

Lacking data and a general understanding of ice-sheet flow far back in time puts up additional constraints, and due to the relatively recent discovery of the NEGIS (Fahnestock et al., 1993), little is known about its evolution in the past. Observations of surface elevation and ice-flow velocities imply that the downstream end of the NEGIS has entered a state of dynamic thinning after at least 25 years of stability (Khan et al., 2014). However, it is not clear for how long the NEGIS has been active and how its catchment geometry has changed over time. The assumption of a constant flow field throughout the past $100 \mathrm{kyr}$ is thus the best currently available, although potentially inaccurate, estimate of the past flow regime.

Our results do not give clear evidence on which of the flow lines gives the best results for upstream corrections. Since the present-day EastGRIP flow line is likely located somewhere between flow line A and C, our results can be interpreted as the outer boundaries and we consider the average over the three flow lines the best estimate for the upstream flow char- 
acteristics with the corresponding model spread as uncertainties.

\section{Conclusions}

We traced isochrones in RES images along three approximated EastGRIP flow lines connecting the EastGRIP and GRIP drill sites. A two-dimensional Dansgaard-Johnsen model was used to simulate the propagation of isochrones along these flow lines. The simplicity of the model allowed us to invert for the ice-flow parameters accumulation rate, basal melt rate, kink height and basal sliding fraction, which give limited but helpful insight into basal properties and iceflow dynamics and can be used to constrain large-scale icesheet models.

On the basis of our modelled two-dimensional velocity field, we calculated particle trajectories backwards in time to determine the deposition site of ice found in the EastGRIP ice core. We present estimates of the upstream distance, surface elevation and accumulation rate at the time and location of ice deposition. This is valuable and necessary information for interpreting ice-core measurements and for separating past climate variability from non-local imprints introduced by upstream effects. Our studies show that spatially increasing accumulation rates with increasing upstream distance along the flow line are mainly responsible for the constant annual layer thicknesses observed for the last $8 \mathrm{kyr}$ in the EastGRIP ice core.

The lack of radar data along the EastGRIP flow line is the biggest limitation of this study. None of the three simulated flow lines accurately represents the present-day flow field but can be regarded as upper and lower limits framing the upstream effects. The acquisition of further radar data along NEGIS flow lines in the future would thus provide more accurate and valuable insights into the flow history of the EastGRIP ice and the NEGIS. 


\section{Appendix A: Notation}

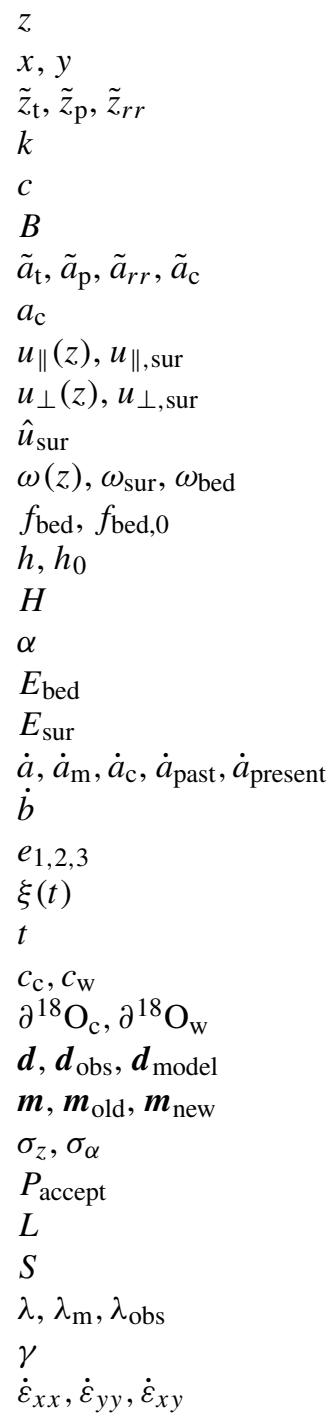

height above bed

direction parallel, perpendicular to the flow profile

total, picking related, radar-related isochrone depth uncertainty

radar window widening factor

speed of light

radar band width

total, picking related, radar related, ice-core-related age uncertainty

ice-core age

flow-line-parallel velocity at depth, at the surface

flow-line-perpendicular velocity at depth, at the surface

normalized surface velocity along the flow line

vertical velocity at depth, at the surface, at the bed

basal sliding fraction, initial basal sliding fraction

kink height, initial kink height

ice thickness

sum of horizontal strain rates $\dot{\varepsilon}_{x x}+\dot{\varepsilon}_{y y}$

bed elevation a.s.l.

surface elevation a.s.l.

positive accumulation rate, Monte Carlo inferred, ice-core inferred, past, present

positive basal melt rate

scaling factors for initial model parameters

climatic scaling factor

time b2k

sensitivity of accumulation rates in cold stadial, warm interstadial periods

typical isotope values for cold stadial, warm interstadial periods

data space, observed, modelled data

model space, old, new model

data uncertainty in isochrone depth, $\alpha_{\text {sur }}$

acceptance probability

likelihood function

misfit function

annual layer thickness, modelled, observed

ice-core thinning function

horizontal strain rates 
Appendix B: Derivation of Eq. (14)

The vertical velocity in the upper part of the ice column is given by

$w(z)=w_{\text {sur }}+\alpha_{\text {sur }}(H-z)=\frac{\mathrm{d} z}{\mathrm{~d} t}, z \in[h, H]$.

Assuming that the surface slope is close to zero, $\frac{\partial E_{\text {sur }}}{\partial x} \simeq 0$, integration of Eq. (B1) with separation of variables results in

$$
\begin{aligned}
& \int_{z}^{H} \frac{1}{-\dot{a}+\alpha_{\text {sur }}(H-z)} \mathrm{d} z=\int_{t}^{0} 1 \mathrm{~d} t, \\
& {\left[-\frac{1}{\alpha_{\text {sur }}} \ln \left(\alpha_{\text {sur }}(H-z)-\dot{a}\right)\right]_{z}^{H}=[t]_{t}^{0},} \\
& -\frac{1}{\alpha_{\text {sur }}}\left(\ln (-\dot{a})-\ln \left(\alpha_{\text {sur }}(H-z)-\dot{a}\right)\right)=-t, \\
& (H-z)=\frac{\dot{a}}{\alpha_{\text {sur }}}\left(1-\mathrm{e}^{-\alpha_{\text {sur }} t}\right) .
\end{aligned}
$$

\section{Appendix C: Definition of the misfit function $S(m)$}

The function $S(\boldsymbol{m})$ is defined as

$S(\boldsymbol{m})=\frac{1}{2}\left(\frac{1}{10} \sum_{l=1}^{10}\left(\frac{1}{n_{z}} \sum_{n=1}^{n_{z}} \mathbf{M}_{z}^{2}\right)+\frac{1}{n_{\alpha}} \sum_{n=1}^{n_{\alpha}} \boldsymbol{M}_{\alpha}^{2}\right)$

$\cdot 1000$,

where $l$ runs through the 10 layers, $n_{z}$ and $n_{\alpha}$ are the number of observed isochrone depths and $\alpha_{\text {sur }}$ along the flow lines, and

$\mathbf{M}_{z}=\frac{\mathbf{d}_{\mathrm{mod}, z}-\mathbf{d}_{\mathrm{obs}, z}}{\sigma_{z}}$ and $\boldsymbol{M}_{\alpha}=\frac{\boldsymbol{d}_{\mathrm{mod}, \alpha}-\boldsymbol{d}_{\mathrm{obs}, \alpha}}{\sigma_{\alpha}}$.

The matrix $\mathbf{M}_{z}$ describes the misfit between modelled $\left(\mathbf{d}_{\text {mod,z }}\right)$ and observed $\left(\mathbf{d}_{\mathrm{obs}, z}\right)$ isochrones, and the vector $\boldsymbol{M}_{\alpha}$ is the misfit between modelled $\left(\boldsymbol{d}_{\bmod , \alpha}\right)$ and observed $\left(\boldsymbol{d}_{\mathrm{obs}, \alpha}\right) \alpha_{\mathrm{sur}}$. The data uncertainty $\sigma_{z}$ is the maximum depth uncertainty of $13 \mathrm{~m}$, and the uncertainty in $\alpha_{\text {sur }}\left(\sigma_{\alpha}\right)$ is assumed to be $10 \%$ of the maximum observed $\alpha_{\text {sur. }}$. The factor 1000 is a tuning parameter to ensure the acceptance ratio remains between $25 \%$ and $75 \%$. 
Data availability. The CReSIS radio-echo-sounding images used for isochrone tracing are publicly available at https://data.cresis.ku.edu/ (CReSIS, 2021). The AWI RES profiles used in this study are available via Jansen et al. (2020) (https://doi.org/10.1594/PANGAEA.914258). The full dataset is described and published by Franke et al. (2021b). The extended EastGRIP timescale, our derived and approximated flow lines, and an extended version of Table 5 are available in the Supplement to this paper.

Supplement. The supplement related to this article is available online at: https://doi.org/10.5194/tc-15-3655-2021-supplement.

Author contributions. DDJ and TAG designed and carried out the study. AG developed the code used for isochrone tracing. AG and $\mathrm{CSH}$ derived the EastGRIP flow lines. DJ was co-investigator for the AWI radar survey and acquired the data in the field. SF processed the radar data obtained during the EGRIP-NOR-2018 AWI flight campaign. SOR, GS and TAG synchronized the EastGRIP ice core with NorthGRIP and NEEM and extended the timescale to the current drill depth. TAG prepared the manuscript with contributions from all co-authors.

Competing interests. The authors declare that they have no conflict of interest.

Disclaimer. Publisher's note: Copernicus Publications remains neutral with regard to jurisdictional claims in published maps and institutional affiliations.

Acknowledgements. EastGRIP is directed and organized by the Centre for Ice and Climate at the Niels Bohr Institute, University of Copenhagen. It is supported by funding agencies and institutions in Denmark (A. P. Møller Foundation, University of Copenhagen), the USA (US National Science Foundation, Office of Polar Programs), Germany (Alfred Wegener Institute, Helmholtz Centre for Polar and Marine Research), Japan (National Institute of Polar Research and Arctic Challenge for Sustainability), Norway (University of Bergen and Trond Mohn Foundation), Switzerland (Swiss National Science Foundation), France (French Polar Institute Paul-Émile Victor, Institute for Geosciences and Environmental Research), Canada (University of Manitoba) and China (Chinese Academy of Sciences and Beijing Normal University). We acknowledge the use of data and data products from CReSIS generated with support from the University of Kansas; NASA Operation IceBridge grant NNX16AH54G; NSF grants ACI-1443054, OPP-1739003 and IIS-1838230, Lilly Endowment Incorporated; and the Indiana METACyt Initiative. We also acknowledge the use of the CReSIS toolbox from CReSIS generated with support from the University of Kansas; NASA Operation IceBridge grant NNX16AH54G; and NSF grants ACI1443054, OPP-1739003 and IIS-1838230. We thank the crew of the research aircraft Polar 6 and system engineer Lukas Kandora for their work during the AWI flight campaign 2018 and express our gratitude to John Paden and Tobias Binder, who helped with the data acquisition during the AWI survey. Sune Olander Rasmussen and Giulia Sinnl gratefully acknowledge the Carlsberg Foundation for supporting the project ChronoClimate. We further thank the two anonymous reviewers for comments and suggestions which helped improving the manuscript. This research was enabled in part by computing facilities and support provided by WestGrid (http://www.westgrid.ca, last access: 30 July 2021) and Compute Canada - Calcul Canada (http://www.computecanada.ca, last access: 30 July 2021). The scientific colour maps "hawaii" and "roma" (Crameri, 2020) are used in this study to prevent visual distortion of the data and exclusion of readers with colour vision deficiencies (Crameri et al., 2020).

Financial support. This research has been supported by the Villum Investigator Project IceFlow (grant no. 16572).

Review statement. This paper was edited by Alexander Robinson and reviewed by two anonymous referees.

\section{References}

Ageta, Y., Azuma, N., Fujii, Y., Fujino, K., Fujita, S., Furukawa, T., Hondoh, T., Kameda, T., Kamiyama, K., Katagiri, K., Kawada, K., Kawamura, T., Kobayashi, S., Mae, S., Maeno, H., Miyahara, T., Motoyama, H., Nakayama, Y., Naruse, R., Nishio, F., Saitoh, K., Saitoh, T., Shimbori, K., Shiraiwa, T., Shoji, H., Takahashi, A., Takahashi, S., Tanaka, Y., Yokoyama, K., and Watanabe, O.: Deep ice-core drilling at Dome Fuji and glaciological studies in east Dronning Maud Land, Antarctica, Ann. Glaciol., 27, 333-337, https://doi.org/10.3189/1998aog27-1-333-337, 1998.

Aizen, V. B., Aizen, E. M., Joswiak, D. R., Fujita, K., Takeuchi, N., and Nikitin, S. A.: Climatic and atmospheric circulation pattern variability from ice-core isotope/geochemistry records (Altai, Tien Shan and Tibet), Ann. Glaciol., 43, 49-60, https://doi.org/10.3189/172756406781812078, 2006.

Alley, R. B., Bolzan, J. F., and Whillans, I. M.: Polar firn densification and grain growth, Ann. Glaciol., 3, 7-11, https://doi.org/10.3189/S0260305500002433, 1982.

Alley, R. B., Meese, D. A., Shuman, C. A., Gow, A. J., Taylor, K. C., Grootes, P. M., White, J. W., Ram, M., Waddington, E. D., Mayewski, P. A., and Zielinski, G. A.: Abrupt increase in Greenland snow accumulation at the end of the Younger Dryas event, Nature, 362, 527-529, https://doi.org/10.1038/362527a0, 1993.

Alley, R. B., Pollard, D., Parizek, B. R., Anandakrishnan, S., Pourpoint, M., Stevens, N. T., MacGregor, J. A., Christianson, K., Muto, A., and Holschuh, N.: Possible Role for Tectonics in the Evolving Stability of the Greenland Ice Sheet, J. Geophys. Res.-Earth, 124, 97-115, https://doi.org/10.1029/2018JF004714, 2019.

Andersen, J. K., Kusk, A., Boncori, J. P. M., Hvidberg, C. S., and Grinsted, A.: Improved ice velocity measurements with Sentinel-1 TOPS interferometry, Remote Sens.-Basel, 12, 1-22, https://doi.org/10.3390/rs12122014, 2020.

Andersen, K. K., Azuma, N., Barnola, J. M., Bigler, M., Biscaye, P., Caillon, N., Chappellaz, J., Clausen, H. B., Dahl-Jensen, D., Fis- 
cher, H., Flückiger, J., Fritzsche, D., Fujii, Y., Goto-Azuma, K., Grønvold, K., Gundestrup, N. S., Hansson, M., Huber, C., Hvidberg, C. S., Johnsen, S. J., Jonsell, U., Jouzel, J., Kipfstuhl, S., Landais, A., Leuenberger, M., Lorrain, R., Masson-Delmotte, V., Miller, H., Motoyama, H., Narita, H., Popp, T., Rasmussen, S. O., Raynaud, D., Rothlisberger, R., Ruth, U., Samyn, D., Schwander, J., Shoji, H., Siggard-Andersen, M. L., Steffensen, J. P., Stocker, T., Sveinbjörnsdóttir, A. E., Svensson, A., Takata, M., Tison, J. L., Thorsteinsson, T., Watanabe, O., Wilhelms, F., and White, J. W.: High-resolution record of Northern Hemisphere climate extending into the last interglacial period, Nature, 431, 147-151, https://doi.org/10.1038/nature02805, 2004.

Andersen, K. K., Svensson, A., Johnsen, S. J., Rasmussen, S. O., Bigler, M., Röthlisberger, R., Ruth, U., Siggaard-Andersen, M. L., Peder Steffensen, J., DahlJensen, D., Vinther, B. M., and Clausen, H. B.: The Greenland Ice Core Chronology 2005, 15-42 ka. Part 1: constructing the time scale, Quaternary Sci. Rev., 25, 3246-3257, https://doi.org/10.1016/j.quascirev.2006.08.002, 2006.

Aschwanden, A., Fahnestock, M. A., and Truffer, M.: Complex Greenland outlet glacier flow captured, Nat. Commun., 7, 1-8, https://doi.org/10.1038/ncomms 10524, 2016.

Barbante, C., Barnola, J. M., Becagli, S., Beer, J., Bigler, M., Boutron, C., Blunier, T., Castellano, E., Cattani, O., Chappellaz, J., Dahl-Jensen, D., Debret, M., Delmonte, B., Dick, D., Falourd, S., Faria, S., Federer, U., Fischer, H., Freitag, J., Frenzel, A., Fritzsche, D., Fundel, F., Gabrielli, P., Gaspari, V., Gersonde, R., Graf, W., Grigoriev, D., Hamann, I., Hansson, M., Hoffmann, G., Hutterli, M. A., Huybrechts, P., Isaksson, E., Johnsen, S., Jouzel, J., Kaczmarska, M., Karlin, T., Kaufmann, P., Kipfstuhl, S., Kohno, M., Lambert, F., Lambrecht, A., Lambrecht, A., Landais, A., Lawer, G., Leuenberger, M., Littot, G., Loulergue, L., Lüthi, D., Maggi, V., Marino, F., MassonDelmotte, V., Meyer, H., Miller, H., Mulvaney, R., Narcisi, B., Oerlemans, J., Oerter, H., Parrenin, F., Petit, J. R., Raisbeck, G., Raynaud, D., Röthlisberger, R., Ruth, U., Rybak, O., Severi, M., Schmitt, J., Schwander, J., Siegenthaler, U., SiggaardAndersen, M. L., Spahni, R., Steffensen, J. P., Stenni, B., Stocker, T. F., Tison, J. L., Traversi, R., Udisti, R., ValeroDelgado, F., Van Den Broeke, M. R., Van De Wal, R. S., Wagenbach, D., Wegner, A., Weiler, K., Wilhelms, F., Winther, J. G., and Wolff, E.: One-to-one coupling of glacial climate variability in Greenland and Antarctica, Nature, 444, 195-198, https://doi.org/10.1038/nature05301, 2006.

Beyer, S., Kleiner, T., Aizinger, V., Rückamp, M., and Humbert, A.: A confined-unconfined aquifer model for subglacial hydrology and its application to the Northeast Greenland Ice Stream, The Cryosphere, 12, 3931-3947, https://doi.org/10.5194/tc-12-39312018, 2018.

Bons, P. D., Jansen, D., Mundel, F., Bauer, C. C., Binder, T., Eisen, O., Jessell, M. W., Llorens, M. G., Steinbach, F., Steinhage, D., and Weikusat, I.: Converging flow and anisotropy cause large-scale folding in Greenland's ice sheet, Nat. Commun., 7, 16, https://doi.org/10.1038/ncomms11427, 2016.

Bons, P. D., de Riese, T., Franke, S., Llorens, M.-G., Sachau, T., Stoll, N., Weikusat, I., Westhoff, J., and Zhang, Y.: Comment on "Exceptionally high heat flux needed to sustain the Northeast Greenland Ice Stream" by Smith-Johnsen et al. (2020), The
Cryosphere, 15, 2251-2254, https://doi.org/10.5194/tc-15-22512021, 2021.

Buchardt, S. L. and Dahl-Jensen, D.: Estimating the basal melt rate at NorthGRIP using a Monte Carlo technique, Ann. Glaciol., 45, 137-142, https://doi.org/10.3189/172756407782282435, 2007.

Burgess, E. W., Forster, R. R., Box, J. E., Mosley-Thompson, E., Bromwich, D. H., Bales, R. C., and Smith, L. C.: A spatially calibrated model of annual accumulation rate on the Greenland Ice Sheet (1958-2007), J. Geophys. Res.-Earth, 115, 1-14, https://doi.org/10.1029/2009JF001293, 2010.

Byers, K. J., Harish, A. R., Seguin, S. A., Leuschen, C. J., Rodriguez-Morales, F., Paden, J., Arnold, E. J., and Hale, R. D.: A modified wideband dipole antenna for an airborne VHF ice-penetrating radar, IEEE T. Instrum. Meas., 61, 1435-1444, https://doi.org/10.1109/TIM.2011.2181780, 2012.

Catania, G., Hulbe, C., and Conway, H.: Groundingline basal melt rates determined using radar-derived internal stratigraphy, J. Glaciol., 56, 545-554, https://doi.org/10.3189/002214310792447842, 2010.

Christianson, K., Parizek, B. R., Alley, R. B., Horgan, H. J., Jacobel, R. W., Anandakrishnan, S., Keisling, B. A., Craig, B. D., and Muto, A.: Ice sheet grounding zone stabilization due to till compaction, Geophys. Res. Lett., 40, 5406-5411, https://doi.org/10.1002/2013GL057447, 2013.

Christianson, K., Peters, L. E., Alley, R. B., Anandakrishnan, S., Jacobel, R. W., Riverman, K. L., Muto, A., and Keisling, B. A.: Dilatant till facilitates ice-stream flow in northeast Greenland, Earth Planet. Sc. Lett., 401, 57-69, https://doi.org/10.1016/j.epsl.2014.05.060, 2014.

Crameri, F.: Scientific colour maps, Zenodo [code], https://doi.org/10.5281/zenodo.4153113, 2020.

Crameri, F., Shephard, G. E., and Heron, P. J.: The misuse of colour in science communication, Nat. Commun., 11, 1-10, https://doi.org/10.1038/s41467-020-19160-7, 2020.

CReSIS: CReSIS radar data products, available at: https://data. cresis.ku.edu/, last access: 30 July 2021.

Cuffey, K. M. and Clow, G. D.: Temperature, accumulation, and ice sheet elevation in central Greenland through the last deglacial transition, J. Geophys. Res.-Oceans, 102, 2638326396, https://doi.org/10.1029/96JC03981, 1997.

Cuffey, K. M. and Paterson, W. S. B.: The physics of glaciers, Butterworth-Heinemann/Elsevier, Amsterdam, 4th Edn., 2010.

Dahl-Jensen, D., Johnsen, S. J., Hammer, C. U., Clausen, H. B., and Jouzel, J.: Past Accumulation rates derived from observed annual layers in the GRIP ice core from Summit, Central Greenland, Ice in the Climate System, 112, 517-532, https://doi.org/10.1007/978-3-642-85016-5_29, 1993.

Dahl-Jensen, D., Mosegaard, K., Gundestrup, N., Clow, G. D., Johnsen, S. J., Hansen, A. W., and Balling, N.: Past temperatures directly from the Greenland ice sheet, Science, 282, 268-271, https://doi.org/10.1126/science.282.5387.268, 1998.

Dahl-Jensen, D., Gundestrup, N., Gogineni, S. P., and Miller, H.: Basal melt at NorthGRIP modeled from borehole, ice-core and radio-echo sounder observations, Ann. Glaciol., 37, 207-212, https://doi.org/10.3189/172756403781815492, 2003.

Dansgaard, W.: Stable isotopes in precipitation, Tellus, 16, 436468, https://doi.org/10.3402/tellusa.v16i4.8993, 1964. 
Dansgaard, W. and Johnsen, S. J.: A Flow Model and a Time Scale for the Ice Core from Camp Century, Greenland, J. Glaciol., 8, 215-223, https://doi.org/10.3189/s0022143000031208, 1969.

Dansgaard, W., Clausen, H. B., Gundestrup, N., Hammer, C. U., Johnsen, S. F., Kristinsdottir, P. M., and Reeh, N.: A new Greenland deep ice core, Science, 218, 1273-1277, https://doi.org/10.1126/science.218.4579.1273, 1982.

Delaygue, G. and Bard, E.: An Antarctic view of Beryllium-10 and solar activity for the past millennium, Clim. Dynam., 36, 22012218, https://doi.org/10.1007/s00382-010-0795-1, 2011.

Eicher, O., Baumgartner, M., Schilt, A., Schmitt, J., Schwander, J., Stocker, T. F., and Fischer, H.: Climatic and insolation control on the high-resolution total air content in the NGRIP ice core, Clim. Past, 12, 1979-1993, https://doi.org/10.5194/cp-12-19792016, 2016.

Eisen, O., Wilhelms, F., Steinhage, D., and Schwander, J.: Improved method to determine radio-echo sounding reflector depths from ice-core profiles of permittivity and conductivity, J. Glaciol., 52, 299-310, https://doi.org/10.3189/172756506781828674, 2006.

Fahnestock, M., Bindschadler, R., Kwok, R., and Jezek, K.: Greenland Ice Sheet surface properties and ice dynamics from ERS-1 SAR imagery, Science, 262, 1530-1534, https://doi.org/10.1126/science.262.5139.1530, 1993.

Fahnestock, M., Abdalati, W., Joughin, I., Brozena, J., and Gogineni, P.: High geothermal heat flow, basal melt, and the origin of rapid ice flow in central Greenland, Science, 294, 2338-2342, https://doi.org/10.1126/science.1065370, 2001.

Finkel, R. C. and Nishiizumi, K.: Beryllium 10 concentrations in the Greenland Ice Sheet Project 2 ice core from 3-40 ka, J. Geophys. Res.-Oceans, 102, 26699-26706, https://doi.org/10.1029/97JC01282, 1997.

Franke, S., Jansen, D., Binder, T., Dörr, N., Helm, V., Paden, J., Steinhage, D., and Eisen, O.: Bed topography and subglacial landforms in the onset region of the Northeast Greenland Ice Stream, Ann. Glaciol., 61, 143-153, https://doi.org/10.1017/aog.2020.12, 2020.

Franke, S., Jansen, D., Beyer, S., Neckel, N., Binder, T., Paden, J., and Eisen, O.: Complex basal conditions and their influence on ice flow at the onset of the Northeast Greenland Ice Stream, J. Geophys. Res.-Earth, 126, e2020JF005689, https://doi.org/10.1029/2020jf005689, 2021a.

Franke, S., Jansen, D., Binder, T., Paden, J. D., Dörr, N., Gerber, T., Miller, H., Dahl-Jensen, D., Helm, V., Steinhage, D., Weikusat, I., Wilhelms, F., and Eisen, O.: Airborne ultra-wideband radar sounding over the shear margins and along flow lines at the onset region of the Northeast Greenland Ice Stream, Earth Syst. Sci. Data Discuss. [preprint], https://doi.org/10.5194/essd-202191 , in review, 2021b.

Fudge, T. J., Steig, E. J., Markle, B. R., Schoenemann, S. W., Ding, Q., Taylor, K. C., McConnell, J. R., Brook, E. J., Sowers, T., White, J. W., Alley, R. B., Cheng, H., Clow, G. D., Cole-Dai, J., Conway, H., Cuffey, K. M., Edwards, J. S., Lawrence Edwards, R., Edwards, R., Fegyveresi, J. M., Ferris, D., Fitzpatrick, J. J., Johnson, J., Hargreaves, G., Lee, J. E., Maselli, O. J., Mason, W., McGwire, K. C., Mitchell, L. E., Mortensen, N., Neff, P., Orsi, A. J., Popp, T. J., Schauer, A. J., Severinghaus, J. P., Sigl, M., Spencer, M. K., Vaughn, B. H., Voigt, D. E., Waddington, E. D., Wang, X., and Wong, G. J.: Onset of deglacial warming in West Antarc- tica driven by local orbital forcing, Nature, 500, 440-444, https://doi.org/10.1038/nature12376, 2013.

Fudge, T. J., Lilien, D. A., Koutnik, M., Conway, H., Stevens, C. M., Waddington, E. D., Steig, E. J., Schauer, A. J., and Holschuh, N.: Advection and non-climate impacts on the South Pole Ice Core, Clim. Past, 16, 819-832, https://doi.org/10.5194/cp-16819-2020, 2020.

Gardner, A. S., Fahnestock, M. A., and Scambos, T. A.: ITS_LIVE Regional Glacier and Ice Sheet Surface Velocities, National Snow and Ice Data Center [data set], https://doi.org/10.5067/6II6VW8LLWJ7, 2020.

Gogineni, S., Tammana, D., Braaten, D., Leuschen, C., Akins, T., Legarsky, J., Kanagaratnam, P., Stiles, J., Allen, C., and Jezek, K.: Coherent radar ice thickness measurements over the Greenland ice sheet, J. Geophys. Res.-Atmos., 106, 3376133772, https://doi.org/10.1029/2001JD900183, 2001.

Gow, A. J., Ueda, H. T., and Garfield, D. E.: Antarctic ice sheet: Preliminary results of first core hole to bedrock, Science, 161, 10111013, https://doi.org/10.1126/science.161.3845.1011, 1968.

Greene, C. A., Gwyther, D. E., and Blankenship, D. D.: Antarctic Mapping Tools for Matlab, Comput. Geosci., 104, 151-157, https://doi.org/10.1016/j.cageo.2016.08.003, 2017.

Grinsted, A. and Dahl-Jensen, D.: A Monte Carlo-tuned model of the flow in the NorthGRIP area, Ann. Glaciol., 35, 527-530, https://doi.org/10.3189/172756402781817130, 2002.

Hammer, C. U.: Acidity of Polar Ice Cores in Relation to Absolute Dating, Past Volcanism, and Radio-Echoes, J. Glaciol., 25, 359372, https://doi.org/10.3189/s0022143000015227, 1980.

Harrison, C. H.: Radio Echo Sounding of Horizontal Layers in Ice, J. Glaciol., 12, 383-397, https://doi.org/10.3189/s0022143000031804, 1973.

Herron, M. M. and Langway, C. C.: Firn densification: an empirical model, J. Glaciol., 25, 373-385, https://doi.org/10.1017/S0022143000015239, 1980.

Holschuh, N., Christianson, K., and Anandakrishnan, S.: Power loss in dipping internal reflectors, imaged using ice-penetrating radar, Ann. Glaciol., 55, 49-56, https://doi.org/10.3189/2014AoG67A005, 2014.

Holschuh, N., Lilien, D. A., and Christianson, K.: Thermal Weakening, Convergent Flow, and Vertical Heat Transport in the Northeast Greenland Ice Stream Shear Margins, Geophys. Res. Lett., 46, 8184-8193, https://doi.org/10.1029/2019GL083436, 2019.

Hvidberg, C. S., Keller, K., Gundestrup, N. S., Tscherning, C. C., and Forsberg, R.: Mass balance and surface movement of the Greenland ice sheet at summit, Central Greenland, Geophys. Res. Lett., 24, 2307-2310, https://doi.org/10.1029/97GL02280, 1997.

Hvidberg, C. S., Grinsted, A., Dahl-Jensen, D., Khan, S. A., Kusk, A., Andersen, J. K., Neckel, N., Solgaard, A., Karlsson, N. B., Kjær, H. A., and Vallelonga, P.: Surface velocity of the Northeast Greenland Ice Stream (NEGIS): assessment of interior velocities derived from satellite data by GPS, The Cryosphere, 14, 3487-3502, https://doi.org/10.5194/tc-14-3487-2020, 2020.

Jacobel, R. W., Gades, A. M., Gottschling, D. L., Hodge, S. M., and Wright, D. L.: Interpretation of radar-detected internal layer folding in West Antarctic ice streams, J. Glaciol., 39, 528-537, https://doi.org/10.1017/s0022143000016427, 1993.

Jansen, D., Franke, S., Binder, T., Paden, J. D., Steinhage, D., Helm, V., and Eisen, O.: AWI UWB radar data along ice 
flow upstream of the EGRIP drill site at the onset region of the Northeast Greenland Ice Stream, PANGAEA [data set], https://doi.org/10.1594/PANGAEA.914258, 2020.

Johnsen, S. J., Clausen, H. B., Dansgaard, W., Fuhrer, K., Gundestrup, N., Hammer, C. U., Iversen, P., Jouzel, J., Stauffer, B., and Steffensen, J. P.: Irregular glacial interstadials recorded in a new Greenland ice core, Nature, 359, 311-313, https://doi.org/10.1038/359311a0, 1992.

Joughin, I., Fahnestock, M., MacAyeal, D., Bamber, J. L., and Gogineni, P.: Observation and analysis of ice flow in the largest Greenland ice stream, J. Geophys. Res.-Atmos., 106, 34021-34034, https://doi.org/10.1029/2001JD900087, 2001.

Joughin, I., Smith, B. E., and Howat, I. M.: A complete map of Greenland ice velocity derived from satellite data collected over 20 years, J. Glaciol., 64, 1-11, https://doi.org/10.1017/jog.2017.73, 2018.

Jouzel, J., Alley, R. B., Cuffey, K. M., Dansgaard, W., Grootes, P., Hoffmann, G., Johnsen, S. J., Koster, R. D., Peel, D., Shuman, C. A., Stievenard, M., Stuiver, M., and White, J.: Validity of the temperature reconstruction from water isotopes in ice cores, J. Geophys. Res.-Oceans, 102, 26471-26487, https://doi.org/10.1029/97JC01283, 1997.

Keisling, B. A., Christianson, K., Alley, R. B., Peters, L. E., Christian, J. E., Anandakrishnan, S., Riverman, K. L., Muto, A., and Jacobel, R. W.: Basal conditions and ice dynamics inferred from radar-derived internal stratigraphy of the northeast Greenland ice stream, Ann. Glaciol., 55, 127-137, https://doi.org/10.3189/2014AoG67A090, 2014.

Khan, S. A., Kjær, K. H., Bevis, M., Bamber, J. L., Wahr, J., Kjeldsen, K. K., Bjørk, A. A., Korsgaard, N. J., Stearns, L. A., Van Den Broeke, M. R., Liu, L., Larsen, N. K., and Muresan, I. S.: Sustained mass loss of the northeast Greenland ice sheet triggered by regional warming, Nat. Clim. Change, 4, 292-299, https://doi.org/10.1038/nclimate2161, 2014.

Lawver, L. A. and Müller, R. D.: Iceland hotspot track, Geology, 22, 311-314, https://doi.org/10.1130/00917613(1994)022<0311:IHT>2.3.CO;2, 1994.

Letréguilly, A., Reeh, N., and Huybrechts, P.: The Greenland ice sheet through the last glacial-interglacial cycle, Palaeogeography, Palaeoclimatology, Palaeoecology, 90, 385-394, https://doi.org/10.1016/S0031-0182(12)80037-X, 1991.

Leysinger Vieli, G. J., Martín, C., Hindmarsh, R. C., and Lüthi, M. P.: Basal freeze-on generates complex ice-sheet stratigraphy, Nat. Commun., 9, 1-13, https://doi.org/10.1038/s41467018-07083-3, 2018.

Lorius, C., Jouzel, J., Ritz, C., Merlivat, L., Barkov, N. I., Korotkevich, Y. S., and Kotlyakov, V. M.: A 150,000-year climatic record from Antarctic ice, Nature, 316, 591-596, https://doi.org/10.1038/316591a0, 1985.

MacGregor, J. A., Fahnestock, M. A., Catania, G. A., Paden, J. D., Prasad Gogineni, S., Young, S. K., Rybarski, S. C., Mabrey, A. N., Wagman, B. M., and Morlighem, M.: Radiostratigraphy and age structure of the Greenland Ice Sheet, J. Geophys. Res.-Earth, 120, 212-241, https://doi.org/10.1002/2014JF003215, 2015.

MacGregor, J. A., Fahnestock, M. A., Catania, G. A., Aschwanden, A., Clow, G. D., Colgan, W. T., Gogineni, S. P., Morlighem, M., Nowicki, S. M., Paden, J. D., Price, S. F., and Seroussi, H.: A synthesis of the basal thermal state of the
Greenland Ice Sheet, J. Geophys. Res.-Earth, 121, 1328-1350, https://doi.org/10.1002/2015JF003803, 2016.

Marcott, S. A., Bauska, T. K., Buizert, C., Steig, E. J., Rosen, J. L., Cuffey, K. M., Fudge, T. J., Severinghaus, J. P., Ahn, J., Kalk, M. L., McConnell, J. R., Sowers, T., Taylor, K. C., White, J. W., and Brook, E. J.: Centennial-scale changes in the global carbon cycle during the last deglaciation, Nature, 514, 616-619, https://doi.org/10.1038/nature13799, 2014.

Marshall, S. J. and Cuffey, K. M.: Peregrinations of the Greenland Ice Sheet divide in the last glacial cycle: Implications for central Greenland ice cores, Earth Planet. Sc. Lett., 179, 73-90, https://doi.org/10.1016/S0012-821X(00)00108-4, 2000.

Meese, D. A., Gow, A. J., Alley, R. B., Zielinski, G. A., Grootes, P. M., Ram, M., Taylor, K. C., Mayewski, P. A., and Bolzan, J. F.: The Greenland Ice Sheet Project 2 depth-age scale: Methods and results, J. Geophys. Res.-Oceans, 102, 2641126423, https://doi.org/10.1029/97JC00269, 1997.

Metropolis, N., Rosenbluth, A. W., Rosenbluth, M. N., Teller, A. H., and Teller, E.: Equation of state calculations by fast computing machines, J. Chem. Phys., 21, 1087-1092, https://doi.org/10.1063/1.1699114, 1953.

Millar, D.: Acidity levels in ice sheets from radio echo-sounding, Ann. Glaciol., 3, 199-203, https://doi.org/10.3189/S0260305500002779, 1982.

Mojtabavi, S., Wilhelms, F., Cook, E., Davies, S. M., Sinnl, G., Skov Jensen, M., Dahl-Jensen, D., Svensson, A., Vinther, B. M., Kipfstuhl, S., Jones, G., Karlsson, N. B., Faria, S. H., Gkinis, V., Kjær, H. A., Erhardt, T., Berben, S. M. P., Nisancioglu, K. H., Koldtoft, I., and Rasmussen, S. O.: A first chronology for the East Greenland Ice-core Project (EGRIP) over the Holocene and last glacial termination, Clim. Past, 16, 23592380, https://doi.org/10.5194/cp-16-2359-2020, 2020.

Morlighem, M., Williams, C. N., Rignot, E., An, L., Arndt, J. E., Bamber, J. L., Catania, G., Chauché, N., Dowdeswell, J. A., Dorschel, B., Fenty, I., Hogan, K., Howat, I., Hubbard, A., Jakobsson, M., Jordan, T. M., Kjeldsen, K. K., Millan, R., Mayer, L., Mouginot, J., Noël, B. P., O’Cofaigh, C., Palmer, S., Rysgaard, S., Seroussi, H., Siegert, M. J., Slabon, P., Straneo, F., van den Broeke, M. R., Weinrebe, W., Wood, M., and Zinglersen, K. B.: BedMachine v3: Complete Bed Topography and Ocean Bathymetry Mapping of Greenland From Multibeam Echo Sounding Combined With Mass Conservation, Geophys. Res. Lett., 44, 11,051-11,061, https://doi.org/10.1002/2017GL074954, 2017.

Mosegaard, K.: Resolution analysis of general inverse problems through inverse Monte Carlo sampling, Inverse Probl., 14, 405, 1998.

Mosegaard, K. and Tarantola, A.: Monte Carlo sampling of solutions to inverse problems, J. Geophys. Res., 100, 12431 -12447, https://doi.org/10.1029/94jb03097, 1995.

Mottram, R., Simonsen, S. B., Svendsen, S. H., Barletta, V. R., Sørensen, L. S., Nagler, T., Wuite, J., Groh, A., Horwath, M., Rosier, J., Solgaard, A., Hvidberg, C. S., and Forsberg, R.: An integrated view of greenland ice sheet mass changes based on models and satellite observations, Remote Sens.-Basel, 11, 1-26, https://doi.org/10.3390/rs11121407, 2019.

NEEM Community members, Dahl-Jensen, D., Albert, M., Aldahan, A., Azuma, N., Balslev-Clausen, D., Baumgartner, M., Berggren, A.-M., Bigler, M., Binder, T., Blunier, T., Bour- 
geois, J. C., Brook, E. J., Chuchardt, S. L., Buizert, C., Capron, E., Chappellaz, J., Chung, J., Clausen, H. B., Cvijanovic, I., Davis, S. M., Ditlevsen, P., Eicher, O., Fischer, H., Fisher, D. A., Fleet, L., Gfeller, G., Gkinis, V., Gogineni, S., Goto-Azuma, K., Grinsted, A., Gudlaugsdottir, H., Guillevic, M., Hansen, S. B., Hansson, M., Hirabayashi, M., Hong, S., Hur, S. D., Huybrechts, P., Hvidberg, C., Iizuka, Y., Jenk, T., Johnsen, S. J., Jones, T. R., Jouzel, J., Karlsson, N. B., Kawamura, K., Keegan, K., Kettner, E., Kipfstuhl, S., Kjær, H. A., Koutnik, M., Kuramoto, T., Köhler, P., Laepple, T., Landais, A., Langen, P., Larsen, L. B., Leuenberger, D., Leuenberger, M., Leuschen, C., Li, J., Lippenkov, V., Mirtinerie, P., Maselli, O. J., Masson-Delmotte, V., McConnel, J. R., Miller, H., Mini, O., Miyamoto, A., MontagnatRentier, M., Mulvaney, R., Muscheler, R., Orsi, A. J., Paden, J., Panton, C., Pattyn, F., Petit, J. R., Pol, K., Popp, T., Possnert, G., Prié, F., Prokopiou, M., Quique, A., Rasmussen, S. O., Raynaud, D., Ren, J., Reutenauer, C., Ritz, C., Roeckeman, T., Rosen, J. L., Rubino, M., Rybak, O., Samyn, D., Sapart, C. J., Schilt, A., Schmidt, A., Schwander, J., Schüpbach, S., Seierstad, I., Severinghaus, J. P., Sheldon, S., Simonsen, S. B., Sjolte, J., Solgaard, A. M., Sowers, T., Sperlich, P., Steen-Larsen, H. C., Steffen, K., Steffensen, J. P., Steinhage, D., Stocker, T., Stowasser, C., Sturevik, A. S., Sturges, B., Sveinbjörnsdottir, A., Svensson, A., Tison, J.-L., Uetake, J., Vallelonga, P., van de Wal, R. S. W., van der Wel, G., Vaughn, B. H., Vinther, B., Waddington, E., Wegner, A., Weikusat, I., White, J. W. C., Wilhelms, F., Winstrup, M., Witrant, E., Wolff, E., Xiao, C., and Zheng, J.: Eemian interglacial reconstructed from a Greenland folded ice core, Nature, 493, 489-494, https://doi.org/10.1038/nature11789, 2013.

Paren, J. G. and Robin, G. D. Q.: Internal Reflections in Polar Ice Sheets, J. Glaciol., 14, 251-259, https://doi.org/10.3189/s0022143000021730, 1975.

Parrenin, F., Barnola, J.-M., Beer, J., Blunier, T., Castellano, E., Chappellaz, J., Dreyfus, G., Fischer, H., Fujita, S., Jouzel, J., Kawamura, K., Lemieux-Dudon, B., Loulergue, L., MassonDelmotte, V., Narcisi, B., Petit, J.-R., Raisbeck, G., Raynaud, D., Ruth, U., Schwander, J., Severi, M., Spahni, R., Steffensen, J. P., Svensson, A., Udisti, R., Waelbroeck, C., and Wolff, E.: The EDC3 chronology for the EPICA Dome C ice core, Clim. Past, 3, 485-497, https://doi.org/10.5194/cp-3-485-2007, 2007.

Petit, J. R., Raynaud, D., Basile, I., Chappellaz, J., Davisk, M., Ritz, C., Delmotte, M., Legrand, M., Lorius, C., Pe, L., and Saltzmank, E.: Climate and atmospheric history of the past 420,000 years from the Vostok ice core, Antarctica, Nature, 399, 429-436, https://doi.org/10.1038/20859, 1999.

Porter, C., Morin, P., Howat, I., Noh, M.-J., Bates, B., Peterman, K., Keesey, S., Schlenk, M., Gardiner, J., Tomko, K., Willis, M., Kelleher, C., Cloutier, M., Husby, E., Foga, S., Nakamura, H., Platson, M., Wethington, Michael, J., Williamson, C., Bauer, G., Enos, J., Arnold, G., Kramer, W., Becker, P., Doshi, A., D'Souza, C., Cummens, P., Laurier, F., and Bojesen, M.: ArcticDEM, https://doi.org/10.7910/DVN/OHHUKH, 2018.

Raisbeck, G. M., Yiou, F., Jouzel, J., and Stocker, T. F.: Direct north-south synchronization of abrupt climate change record in ice cores using Beryllium 10, Clim. Past, 3, 541-547, https://doi.org/10.5194/cp-3-541-2007, 2007.
Rasmussen, S., Seierstad, I., Andersen, K. K., Bigler, M., Dahl-Jensen, D., and Johnsen, S.: Synchronization of the NGRIP, GRIP, and GISP2 ice cores across MIS 2 and palaeoclimatic implications, Quaternary Sci. Rev., 27, 18-28, https://doi.org/10.1016/j.quascirev.2007.01.016, 2008.

Rasmussen, S. O., Andersen, K. K., Svensson, A. M., Steffensen, J. P., Vinther, B. M., Clausen, H. B., SiggaardAndersen, M. L., Johnsen, S. J., Larsen, L. B., Dahl-Jensen, D., Bigler, M., Röthlisberger, R., Fischer, H., Goto-Azuma, K., Hansson, M. E., and Ruth, U.: A new Greenland ice core chronology for the last glacial termination, J. Geophys. Res.-Atmos., 111, 1-16, https://doi.org/10.1029/2005JD006079, 2006.

Rasmussen, S. O., Abbott, P. M., Blunier, T., Bourne, A. J., Brook, E., Buchardt, S. L., Buizert, C., Chappellaz, J., Clausen, H. B., Cook, E., Dahl-Jensen, D., Davies, S. M., Guillevic, M., Kipfstuhl, S., Laepple, T., Seierstad, I. K., Severinghaus, J. P., Steffensen, J. P., Stowasser, C., Svensson, A., Vallelonga, P., Vinther, B. M., Wilhelms, F., and Winstrup, M.: A first chronology for the North Greenland Eemian Ice Drilling (NEEM) ice core, Clim. Past, 9, 2713-2730, https://doi.org/10.5194/cp-9-2713-2013, 2013.

Rasmussen, S. O., Bigler, M., Blockley, S. P., Blunier, T., Buchardt, S. L., Clausen, H. B., Cvijanovic, I., Dahl-Jensen, D., Johnsen, S. J., Fischer, H., Gkinis, V., Guillevic, M., Hoek, W. Z., Lowe, J. J., Pedro, J. B., Popp, T., Seierstad, I. K., Steffensen, J. P., Svensson, A. M., Vallelonga, P., Vinther, B. M., Walker, M. J. C., Wheatley, J. J., and Winstrup, M.: A stratigraphic framework for abrupt climatic changes during the Last Glacial period based on three synchronized Greenland ice-core records: refining and extending the INTIMATE event stratigraphy, Quaternary Sci. Rev., 106, 14-28, https://doi.org/10.1016/j.quascirev.2014.09.007, 2014.

Raynaud, D., Chappellaz, J., Ritz, C., and Martinerie, P.: Air content along the Greenland Ice Core Project core: A record of surface climatic parameters and elevation in central Greenland, J. Geophys. Res.-Oceans, 102, 26607-26613, https://doi.org/10.1029/97JC01908, 1997.

Rignot, E. and Mouginot, J.: Ice flow in Greenland for the international polar year 2008-2009, Geophys. Res. Lett., 39, 1-7, https://doi.org/10.1029/2012GL051634, 2012.

Riverman, K. L., Alley, R. B., Anandakrishnan, S., Christianson, K., Holschuh, N. D., Medley, B., Muto, A., and Peters, L. E.: Enhanced Firn Densification in High-Accumulation Shear Margins of the NE Greenland Ice Stream, J. Geophys. Res.-Earth, 124, 365-382, https://doi.org/10.1029/2017JF004604, 2019.

Robin, G. d. Q. and Millar, D. H. M.: Flow Of Ice Sheets In The Vicinity Of Subglacial Peaks, Ann. Glaciol., 3, 290-294, https://doi.org/10.3189/s0260305500002949, 1982.

Robin, G. d. Q., Evans, S., and Bailey, J. T.: Interpretation of radio echo sounding in polar ice sheets, Philos. T. R. Soc. S.-A, 265, 437-505, https://doi.org/10.1098/rsta.1969.0063, 1969.

Salamatin, A. N., Lipenkov, V. Y., Barkov, N. I., Jouzel, J., Petit, J. R., and Raynaud, D.: Ice core age dating and paleothermometer calibration based on isotope and temperature profiles from deep boreholes at Vostok Station (East Antarctica), J. Geophys. Res.-Atmos., 103, 8963-8977, https://doi.org/10.1029/97JD02253, 1998.

Seierstad, I. K., Abbott, P. M., Bigler, M., Blunier, T., Bourne, A. J., Brook, E., Buchardt, S. L., Buizert, C., Clausen, H. B., Cook, E., Dahl-Jensen, D., Davies, S. M., 
Guillevic, M., Johnsen, S. J., Pedersen, D. S., Popp, T. J., Rasmussen, S. O., Severinghaus, J. P., Svensson, A., and Vinther, B. M.: Consistently dated records from the Greenland GRIP, GISP2 and NGRIP ice cores for the past 104ka reveal regional millennial-scale $\delta^{18} \mathrm{O}$ gradients with possible Heinrich event imprint, Quaternary Sci. Rev., 106, 29-46, https://doi.org/10.1016/j.quascirev.2014.10.032, 2014.

Simonsen, S. B. and Sørensen, L. S.: Implications of changing scattering properties on Greenland ice sheet volume change from Cryosat-2 altimetry, Remote Sens. Environ., 190, 207-216, https://doi.org/10.1016/j.rse.2016.12.012, 2017.

Smith-Johnsen, S., de Fleurian, B., Schlegel, N., Seroussi, H., and Nisancioglu, K.: Exceptionally high heat flux needed to sustain the Northeast Greenland Ice Stream, The Cryosphere, 14, 841854, https://doi.org/10.5194/tc-14-841-2020, 2020a.

Smith-Johnsen, S., Schlegel, N. J., de Fleurian, B., and Nisancioglu, K. H.: Sensitivity of the Northeast Greenland Ice Stream to Geothermal Heat, J. Geophys. Res.-Earth, 125, 1-14, https://doi.org/10.1029/2019JF005252, 2020b.

Svensson, A., Andersen, K. K., Bigler, M., Clausen, H. B., DahlJensen, D., Davies, S. M., Johnsen, S. J., Muscheler, R., Rasmussen, S. O., Röthlisberger, R., Steffensen, J. P., and Vinther, B. M.: The Greenland ice core chronology 2005, 15-42 ka. Part 2: comparison to other records, Quaternary Sci. Rev., 25, 32583267, https://doi.org/10.1029/2005JD006079, 2006.

Svensson, A., Andersen, K. K., Bigler, M., Clausen, H. B., DahlJensen, D., Davies, S. M., Johnsen, S. J., Muscheler, R., Parrenin, F., Rasmussen, S. O., Röthlisberger, R., Seierstad, I., Steffensen, J. P., and Vinther, B. M.: A 60000 year Greenland stratigraphic ice core chronology, Clim. Past, 4, 47-57, https://doi.org/10.5194/cp-4-47-2008, 2008.

Vallelonga, P., Christianson, K., Alley, R. B., Anandakrishnan, S., Christian, J. E. M., Dahl-Jensen, D., Gkinis, V., Holme, C., Jacobel, R. W., Karlsson, N. B., Keisling, B. A., Kipfstuhl, S., Kjær, H. A., Kristensen, M. E. L., Muto, A., Peters, L. E., Popp, T., Riverman, K. L., Svensson, A. M., Tibuleac, C., Vinther, B. M., Weng, Y., and Winstrup, M.: Initial results from geophysical surveys and shallow coring of the Northeast Greenland Ice Stream (NEGIS), The Cryosphere, 8, 1275-1287, https://doi.org/10.5194/tc-8-1275-2014, 2014.

Vinther, B., Buchardt, S., Clausen, H., Dahl-Jensen, D., Johnsen, S., Fisher, D., Koerner, R., Raynaud, D., Lipenkov, V., Andersen, K. K., Blunier, T., Rasmussen, S. O., Steffensen, J. P., and Svensson, A. M.: Holocene thinning of the Greenland ice sheet, Nature, 461, 385-388, https://doi.org/10.1038/nature08355, 2009.
Vinther, B. M., Clausen, H. B., Johnsen, S. J., Rasmussen, S. O., Andersen, K. K., Buchardt, S. L., Dahl-Jensen, D., Seierstad, I. K., Siggaard-Andersen, M.-L., Steffensen, J. P., Svensson, A., Olsen, J., and Heinemeier, J.: A synchronized dating of three Greenland ice cores throughout the Holocene, J. Geophys. Res.Atmos., 111, D13102, https://doi.org/10.1029/2005JD006921, 2006.

Waddington, E. D., Neumann, T. A., Koutnik, M. R., Marshall, H. P., and Morse, D. L.: Inference of accumulation-rate patterns from deep layers in glaciers and ice sheets, J. Glaciol., 53 , 694-712, https://doi.org/10.3189/002214307784409351, 2007.

Walker, M., Johnes, S., Rasmussen, S. O., Popp, T., Steffensen, J.P., Gibbard, P., Hoek, W., Lowe, J., Andrews, J., Björck, S., Cwynar, L. C., Hughen, K., Kershaw, P., Kromer, B., Litt, T., Lowe, D. J., Nakagawa, T., Newnham, R., and Schwander, J.: Formal definition and dating of the GSSP (Global Stratotype Section and Point) for the base of the Holocene using the Greenland NGRIP ice core, and selected auxiliary records, J. Quaternary Sci., 24, 3-17, https://doi.org/10.1002/jqs.1227, 2009.

Weertman, J.: Sliding-no sliding zone effect and age determination of ice cores, Quaternary Res., 6, 203-207, https://doi.org/10.1016/0033-5894(76)90050-8, 1976.

Whillans, I. M.: Radio-echo layers and the recent stability of the West Antarctic ice sheet, Nature, 264, 152-155, https://doi.org/10.1038/264152a0, 1976.

Whillans, I. M. and Johnsen, S. J.: Longitudinal variations in glacial flow: theory and test using data from the Byrd Station strain network, Antarctica, J. Glaciol., 29, 78-97, https://doi.org/10.1017/S0022143000005165, 1983.

Wolovick, M. J., Creyts, T. T., Buck, W. R., and Bell, R. E.: Traveling slippery patches produce thickness-scale folds in ice sheets, Geophys. Res. Lett., 41, 8895-8901, https://doi.org/10.1002/2014GL062248, 2014.

Yiou, F., Raisbeck, G. M., Baumgartner, S., Beer, J., Hammer, C., Johnsen, S., Jouzel, J., Kubik, P. W., Lestringuez, J., Stiévenard, M., Suter, M., and Yiou, P.: Beryllium 10 in the Greenland Ice Core Project ice core at Summit, Greenland, J. Geophys. Res.-Oceans, 102, 26783-26794, https://doi.org/10.1029/97JC01265, 1997.

Zeising, O. and Humbert, A.: Indication of high basal melting at the EastGRIP drill site on the Northeast Greenland Ice Stream, The Cryosphere, 15, 3119-3128, https://doi.org/10.5194/tc-15-31192021, 2021. 